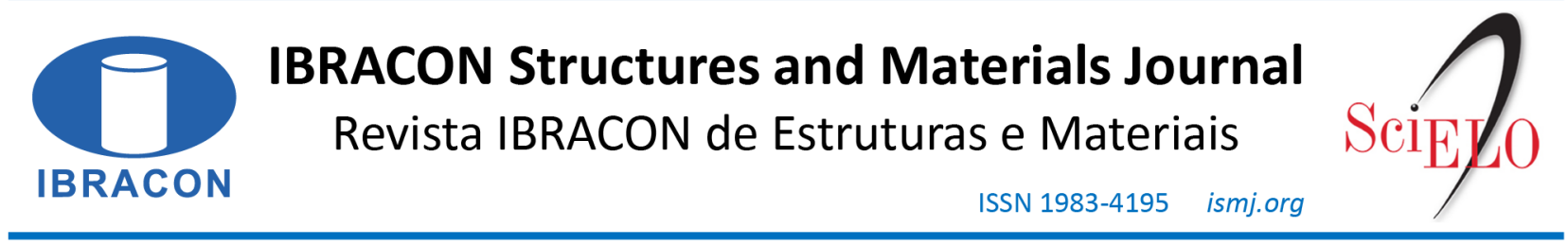

ORIGINAL ARTICLE

\title{
Influence of recycled concrete aggregates on the shear strength of reinforced concrete beams
}

\section{Influência dos agregados reciclados de concreto na resistência ao cisalhamento de vigas de concreto armado}

\author{
Allan Carvalho Cardoso ${ }^{\mathrm{a}}$ (i) \\ Isaque Guerreiro Lima ${ }^{\mathrm{a}}$ (D) \\ Maurício de Pina Ferreira $^{\mathrm{a}}$ (D) \\ Rafael Alves de Souza ${ }^{\mathrm{b}}$ (i)
}

\footnotetext{
${ }^{a}$ Universidade Federal do Pará - UFPA, Instituto de Tecnologia, Belém, PA, Brasil

bUniversidade Estadual de Maringá - UEM, Departamento de Engenharia Civil, Maringá, PR, Brasil
}

Received 21 January 2019

Accepted 26 May 2020

\begin{abstract}
This research evaluates the influence of the replacement of natural coarse aggregates (NCA) by recycled concrete aggregates (RCA) on the shear strength of reinforced concrete beams. Experimental tests on six reinforced concrete beams with RCA replacement ratios of $0 \%, 30 \%$, and $100 \%$ are presented. Furthermore, a database with results of 170 tests on beams with RCA is used to discuss adjustments in the recommendations presented by ABNT NBR 6118 to estimate the shear strength of reinforced concrete beams. According to the Demerit Points Classification (DPC) proposed by Collins, $80 \%$ of the theoretical results obtained using models I and II from the Brazilian code fall in an appropriate safety condition range, showing that the substitution of NCA by RCA has a low impact on the shear strength reinforced concrete beams.
\end{abstract}

Keywords: shear, recycled concrete aggregates, reinforced concrete.

Resumo: Esta pesquisa avaliou a influência da substituição de agregados graúdos naturais (AGN) por agregados reciclados de concreto (ARC) na resistência ao cisalhamento de vigas de concreto armado. Ensaios experimentais em seis vigas de concreto armado com taxas de substituição de ARC de $0 \%, 30 \%$ e $100 \%$ são apresentados. Além disso, um banco de dados com resultados de 170 ensaios em vigas com ARC é utilizado para discutir os ajustes nas recomendações apresentadas pela ABNT NBR 6118 para estimar a resistência ao cisalhamento de vigas de concreto armado. Segundo o Demerit Points Classification (DPC), proposto por Collins, $80 \%$ dos resultados teóricos obtidos com os modelos I e II da norma brasileira caem dentro de uma faixa considerada de segurança apropriada, mostrando que a substituição dos AGN por ARC tem baixa influência na resistência ao cisalhamento de vigas de concreto armado.

Palavras-chave: cisalhamento, agregados reciclados de concreto, concreto armado.

How to cite: A. C. Cardoso, I. G. Lima, M. P. Ferreira, and R. A. Souza, "Influence recycled concrete aggregates on the shear strength of reinforced concrete beams," Rev. IBRACON Estrut. Mater., vol. 14, no. 1, e14109, 2021, https://doi.org/10.1590/S1983-41952021000100009

\section{INTRODUCTION}

Civil construction is one of the leading industrial sectors and contributes significantly to economic growth and social development. In this context, the aggregate industry is an important segment, as according to Langer et al. [1], on a global level, it involves the exploration of significant quantities of non-renewable natural resources. The civil construction industry is also considered a relevant waste generating agent. Pinto [2] presents and discusses the high numbers of construction and demolition waste (CDW) production in Brazil. More recent data (see [3]), provided by the Brazilian Association of Public Cleaning and Special Waste Companies (ABRELPE), indicate that in 2018, the total 
quantity of CDW collected by the cities in the country was of 122,012 tonnes/day, resulting in a per capita generation of $0.585 \mathrm{~kg} /$ inhabitant/day.

The use of CDW in non-structural or structural concrete production has been the focus of intense scientific studies. This theme is also relevant considering the expected increase of concrete consumption and, therefore, of coarse aggregate, as highlighted by Arezoumandi et al. [4]. Rahal and Alrefaei [5] investigated the effect of replacing natural coarse aggregate (NCA) by RCA and did not observe any damaging effects in the shear strength of reinforced concrete beams for replacement rates until $16 \%$. For beams with shear reinforcement, Ignjatović et al. [6] did not observe significant changes in both behaviour and shear strength for NCA to RCA replacement rates of 0,50 , and $100 \%$.j

From a theoretical point of view, it is expected that the change of aggregates will affect the shear strength since it may alter the roughness of the failure plane, reducing the contribution of concrete through aggregate interlock. For structural elements with high flexural reinforcement ratio $\left(\rho_{1}\right)$, these effects may be even more significant because crack widths are wider at failure. These variables (aggregate interlock and $\rho_{\mathrm{l}}$ ) were the target of some classic shear investigations, such as those carried by Taylor [7] to Poli et al. [8], or more recent research, such as those presented by Ulaga [9] and Sagaseta and Vollum [10].

This paper presents an experimental and theoretical investigation about the influence of the replacement of NCA by RCA on the shear strength of reinforced concrete beams without and with shear reinforcement. These results are used to evaluate the need for adjustments in the current recommendations presented by ABNT NBR 6118 [11], in case it is used to predict the shear strength of reinforced concrete beams with the replacement of NCA by RCA.

\section{LITERATURE REVIEW}

The impact of the replacement of NCA by RCA in the compressive strength of concrete can vary significantly. Studies from [7] and [12] to [13] indicate a 30\% reduction in the concrete strength due to the replacement of NCA by RCA. On the other hand, according to [14] and [15], the reduction can reach up to 76\%. The loss of strength is more pronounced if recycled concrete aggregates from an unknown source are used. The use of RCA produced from the waste of high-strength concrete $\left(f_{\mathrm{c}} \geq 50 \mathrm{MPa}\right)$ will result in a compressive strength comparable with those obtained with NCA, that according to Schubert et al. [16], is related to the aggregate's water absorption. Cordeiro et al. [17] describe that it is possible to optimize RCA characteristics by incorporating reactive and non-reactive fines, improving the performance of concretes made with RCA.

In structural terms, [6] and [18] concluded that there is a similarity in both the crack pattern and the cracking load for reinforced concrete beams without stirrups, regardless of whether the concrete was produced with NCA or RCA. [6] also reports that no significant reductions in the shear strengths were measured. However, according to Rahal and Alrefaei [5], replacements of $23 \%$ and $35 \%$ led to a shear strength reduction of $10 \%$ and $21 \%$, respectively. In the case of beams with shear reinforcement, these authors did not measure significant reductions in the shear strength, regardless of the amount of RCA. The shear-span can be another parameter to be investigated, as Choi et al. [19] observed pronounced reductions in the shear strength due to RCA's use in beams with a lower a/d ratio. Regarding the design standards, González-Fonteboa and Martínez-Abella [20] observed a better correlation between theoretical estimates of shear strength and experimental results for beams without shear reinforcement, which is not allowed in practice, than for those with stirrups, pointing that this is a topic that deserves more scientific efforts.

\section{MATERIALS AND METHODS}

\subsection{Experimental program}

The concrete used to cast the tested beams was produced with 0,30 , and $100 \%$ replacement rates of NCA by RCA. Basaltic gravel with a maximum size of $25 \mathrm{~mm}$ was used as a natural coarse aggregate. As a fine aggregate, medium natural sand was used. The coarse recycled concrete aggregates were produced at the Civil Engineering Laboratory of the Federal University of Pará. For their production, the laboratory's structural concrete wastes were carefully selected to guarantee that only regular strength concrete $\left(f_{\mathrm{c}}<50 \mathrm{MPa}\right)$ was used as origin material.

The RCA production process consisted of grinding the wastes with a jaw crusher. After this procedure, all the material was sieved, following the recommendations of ABNT NBR NM 248 [21], and separated into different granulometric ranges. The methods adopted by the Brazilian and international standards, used for 
natural aggregates, can be unsuitable for RCA. For this reason, the methodology proposed by Leite [22] was used to determine the aggregate specific gravity of the RCA. Figure 1 shows the granulometric composition of the aggregates and their main characteristics.

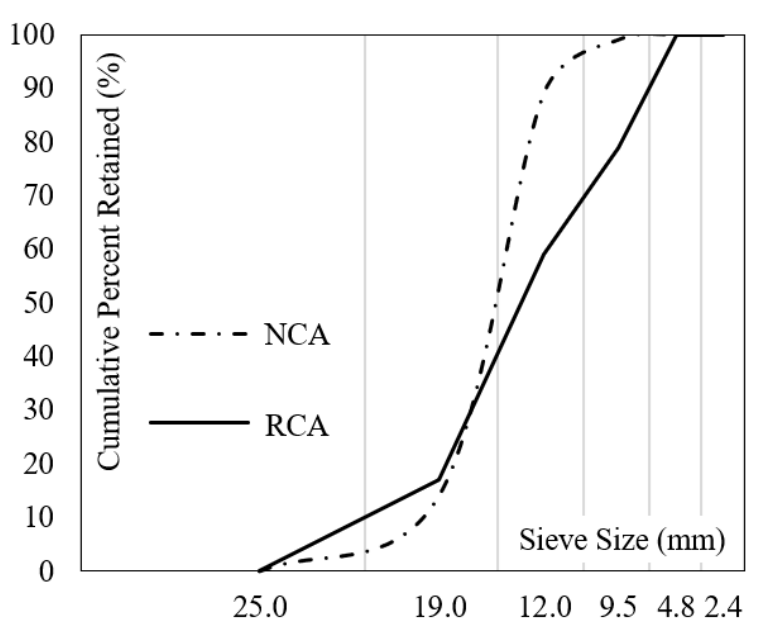

a) The granulometric curve of coarse aggregate

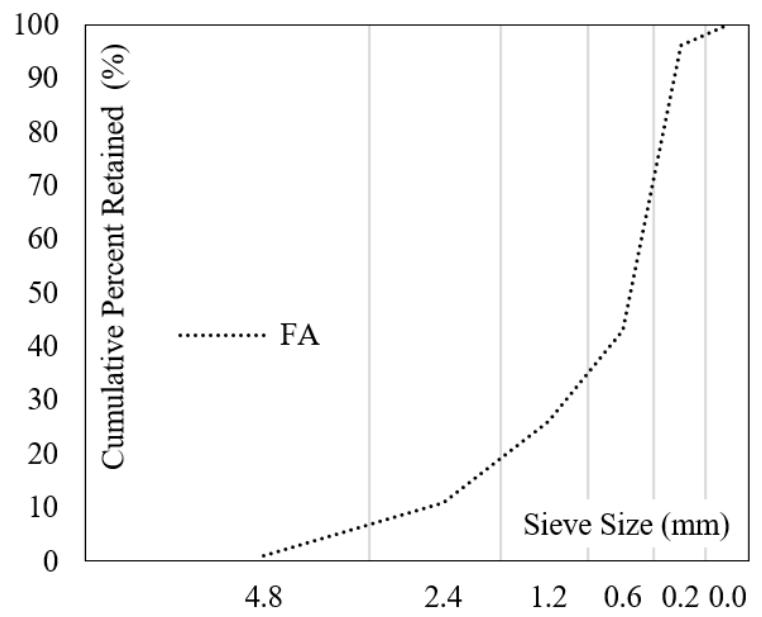

b) The granulometric curve of fine aggregate

\begin{tabular}{|l|c|c|c|}
\hline & FA & NCA & RCA \\
\hline $\begin{array}{l}\text { Fineness } \\
\text { Modulus }\end{array}$ & 2.61 & 7 & 6.96 \\
\hline $\begin{array}{l}\text { Maximum } \\
\text { Size }\end{array}$ & $4.8 \mathrm{~mm}$ & $25 \mathrm{~mm}$ & $25 \mathrm{~mm}$ \\
\hline $\begin{array}{l}\text { Specific } \\
\text { Gravity }\end{array}$ & $2.61 \mathrm{~g} / \mathrm{cm}^{3}$ & $2.62 \mathrm{~g} / \mathrm{cm}^{3}$ & $2.66 \mathrm{~g} / \mathrm{cm}^{3}$ \\
\hline $\begin{array}{l}\text { Unit } \\
\text { Weight }\end{array}$ & $1.67 \mathrm{~g} / \mathrm{cm}^{3}$ & $1.34 \mathrm{~g} / \mathrm{cm}^{3}$ & $1.11 \mathrm{~g} / \mathrm{cm}^{3}$ \\
\hline
\end{tabular}

c) Properties of coarse and fine aggregates

Figure 1. Aggregates characterization.

The concrete proportioning was set to achieve a C30 strength class and was based on the design curves presented by Santos et al. [23], using high early strength Portland cement CP-V ARI RS. The concrete's workability was measured by slump tests, following the recommendations presented by ABNT NBR NM 67 [24]. The slump values were defined as $15 \pm 2 \mathrm{~cm}$ for both concrete with NCA and RCA. The wet curing of the concrete beams and specimens was initiated after the concrete's surface hardening. The beams and the cylindric samples used to characterize the concrete's mechanical properties were wet-cured for seven days.

Six reinforced concrete beams with a 2,200 $\mathrm{mm}$ length and rectangular section (180 mm width and $280 \mathrm{~mm}$ height) were tested. Two beams served as reference and were cast with NCA concrete, one without shear reinforcement and the other with closed stirrups. The rest of the beams were cast with concrete with $30 \%$ and $100 \%$ replacement of NCA by RCA, having or not shear stirrups. All the beams had $\rho_{1}$ equal to $2.13 \%$, about half of the maximum value allowed by the ABNT NBR 6118 [11]. The beams with stirrups had a shear reinforcement ratio of $0.10 \%$. Table 1 and Figure 2 show the main characteristics of the tested beams. 
Table 1. Characteristics of the tested beams.

\begin{tabular}{|c|c|c|c|c|c|c|c|c|}
\hline Specimen & $\%$ of RCA & $d(\mathrm{~mm})$ & $a(\mathrm{~mm})$ & $a / d$ & $\sigma_{\mathrm{f}}(\mathbf{m m})$ & $\boldsymbol{\sigma}_{w}(\mathbf{m m})$ & $\rho_{1}(\%)$ & $\rho_{\mathrm{w}}(\%)$ \\
\hline V0 & \multirow{2}{*}{0} & \multirow{2}{*}{246} & \multirow{6}{*}{620} & \multirow{2}{*}{2.52} & \multirow{2}{*}{20} & 0 & \multirow{2}{*}{2.13} & 0 \\
\hline W0 & & & & & & 4.2 & & 0.10 \\
\hline V30 & \multirow{2}{*}{30} & \multirow{2}{*}{246} & & \multirow{2}{*}{2.52} & \multirow{2}{*}{20} & 0 & \multirow{2}{*}{2.13} & 0 \\
\hline W30 & & & & & & 4.2 & & 0.10 \\
\hline V100 & \multirow{2}{*}{100} & \multirow{2}{*}{246} & & \multirow{2}{*}{2.52} & \multirow{2}{*}{20} & 0 & \multirow{2}{*}{2.13} & 0 \\
\hline W100 & & & & & & 4.2 & & 0.10 \\
\hline
\end{tabular}

Note: $b_{w}=180 \mathrm{~mm} ; h=280 \mathrm{~mm} ; L=2200 \mathrm{~mm} ; c=20 \mathrm{~mm} ; f_{c}=30 \mathrm{MPa} ; f_{y s}=500 \mathrm{MPa} ; \alpha=90^{\circ} ; \rho_{\mathrm{w}}=A_{s w} /\left(b_{w} \cdot s\right) ; \rho_{1}=A_{s w} /\left(b_{w} \cdot d\right)$

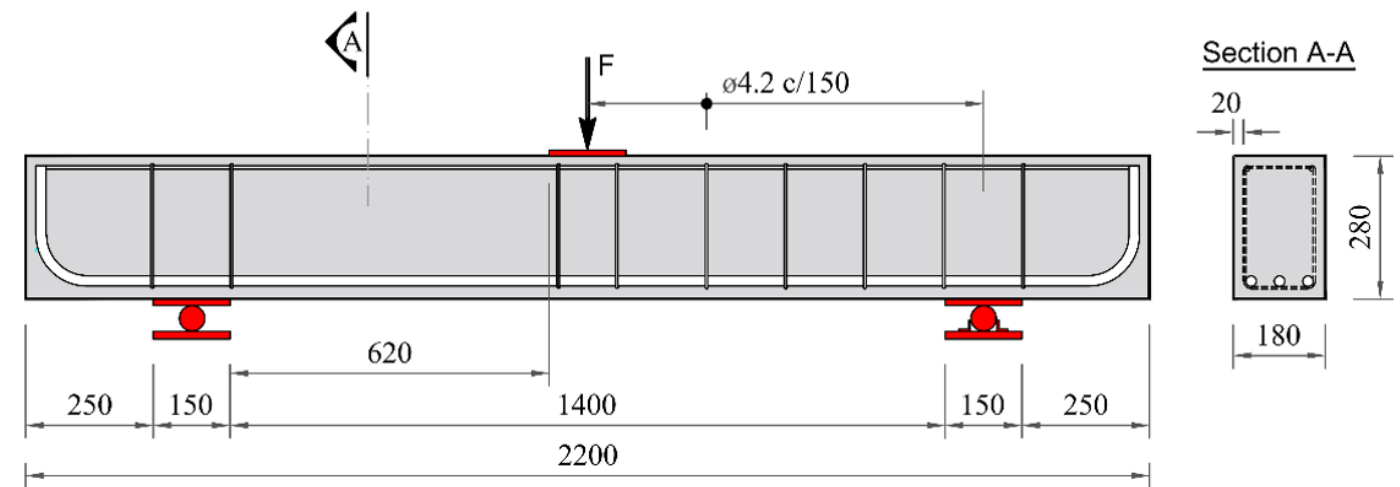

a) Side view and cross-section of the beams without shear reinforcement

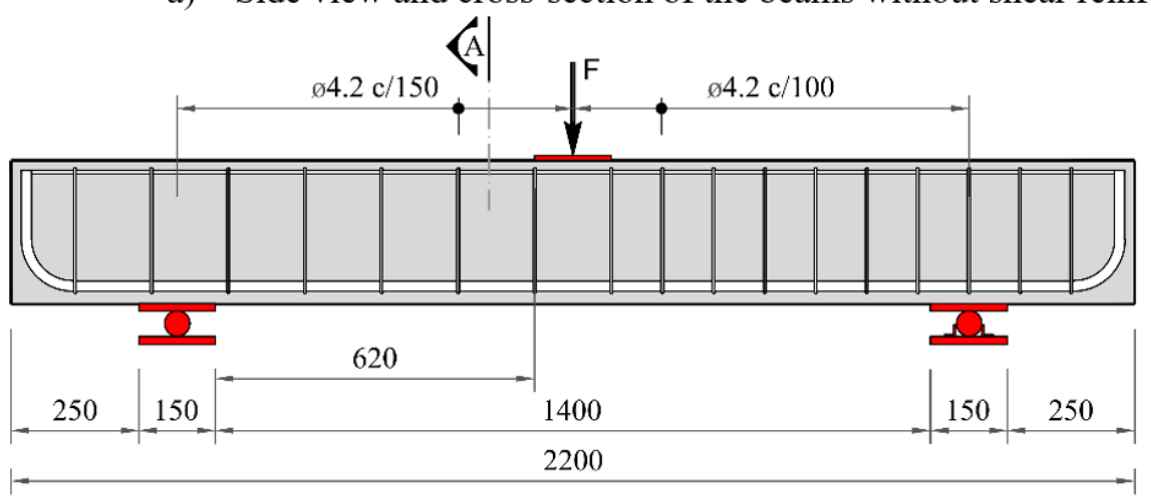

$\underline{\text { Section A-A }}$

20

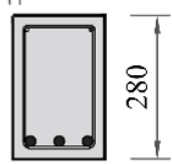

$+180$

b) Side view and cross-section of the beams with shear reinforcement

Figure 2. Flexural and shear reinforcement of the tested beams

The tested beams had two symmetrical spans with different amounts of shear reinforcement to guarantee that failure would occur in the weaker side where the strain gauges were placed. Figure 2 shows that the beams' left span is the weak side and was the focus of this experimental investigation. The beams denominated as "V" do not have stirrups on the left span and the beams denominated as "W" had closed stirrups made with $4.2 \mathrm{~mm}$ bars spaced at each $150 \mathrm{~mm}$. For the flexural reinforcement, three steel bars with $20 \mathrm{~mm}$ of diameter distributed on a single layer were used, as shown in Figure 2.

Simply supported beams with three-point loading were tested. The supports were made with double "I" steel profiles in which two steel plates ( $150 \mathrm{~mm}$ wide and $20 \mathrm{~mm}$ thick) and one roller (40 mm diameter) were attached. The load was applied using a testing machine in $5 \mathrm{kN}$ load steps, and its intensity was continuously measured by a load cell connected to an electronic acquisition data system. Figure 3 shows the testing system.

A potentiometric linear displacement transducer attached to a yoke was used to measure the vertical displacements (see Figure 4a). One pair of strain gauges was used to measure the flexural reinforcement strains, as shown in Figure $4 \mathrm{~b}$. Strains in the shear reinforcement were also measured by pairs of strain gauges attached to 3 layers of stirrups, as shown 
in Figure 4c. The results presented for the flexural and shear reinforcement strains refer to the mean values of the pairs of strain gauges.

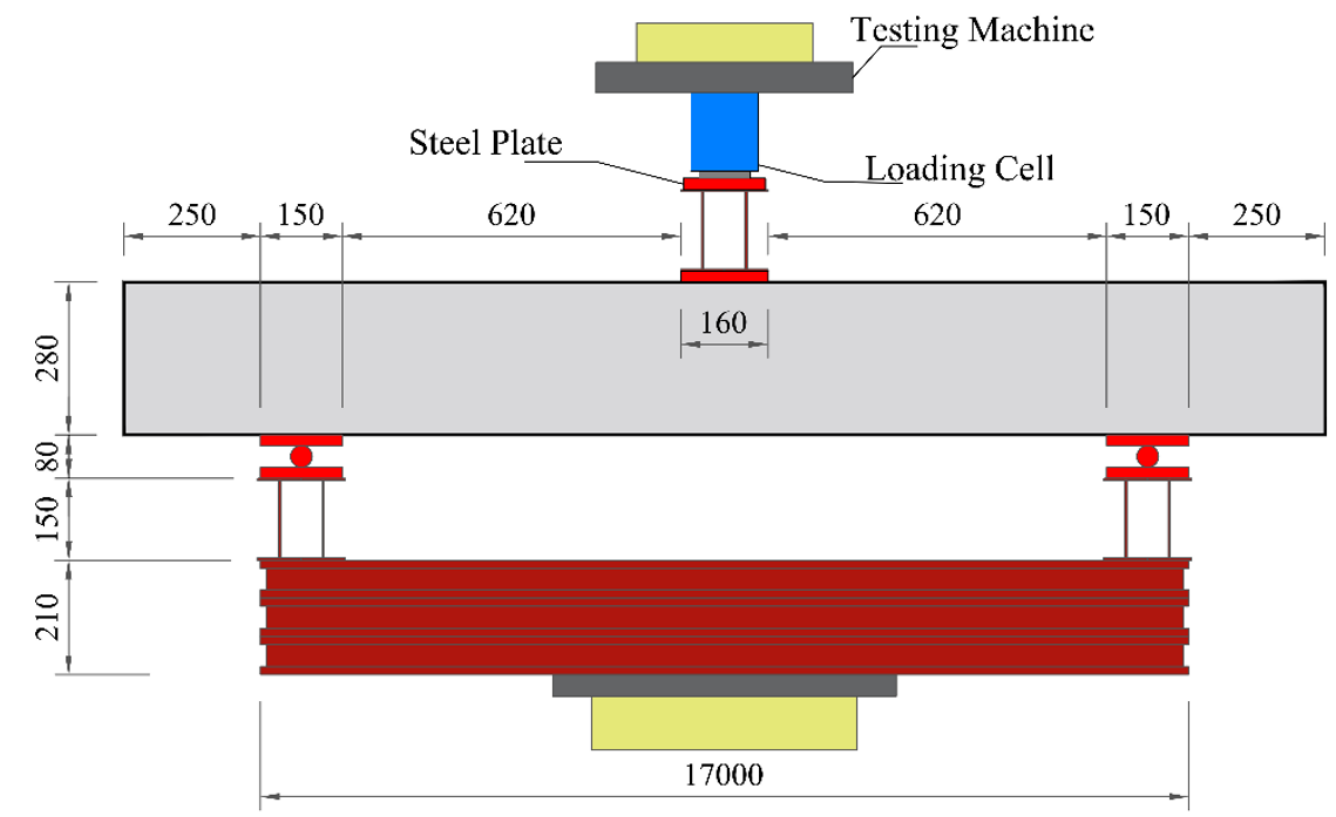

Figure 3. Testing setup

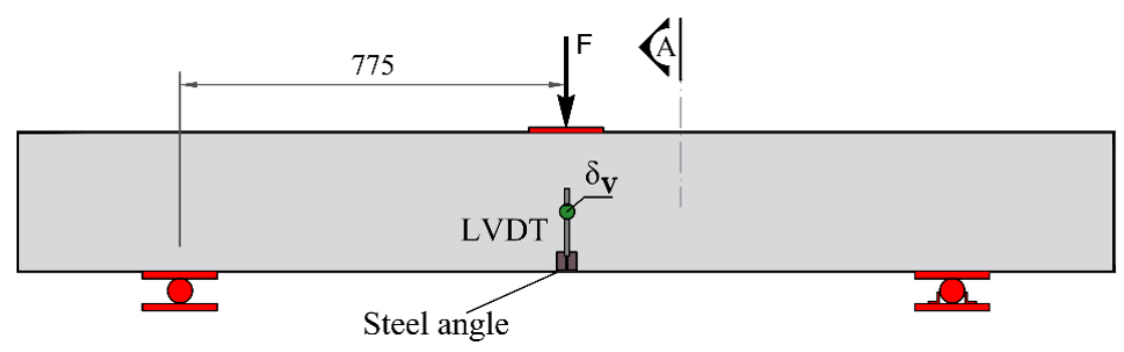

a) Vertical displacement

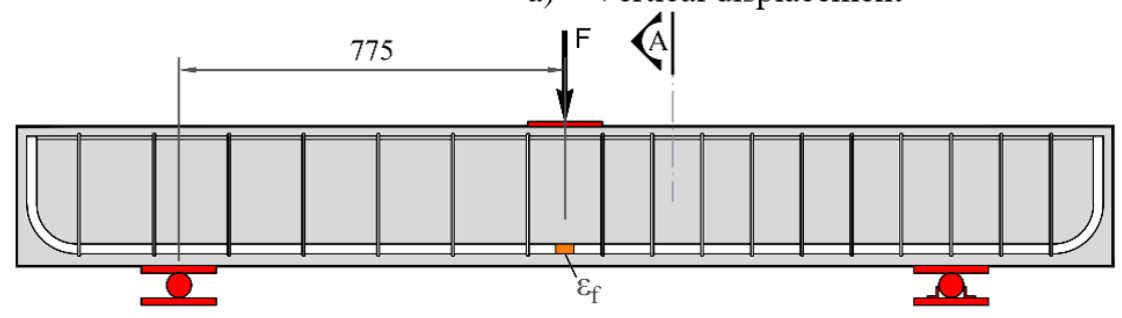

b) Strains in the flexural reinforcement

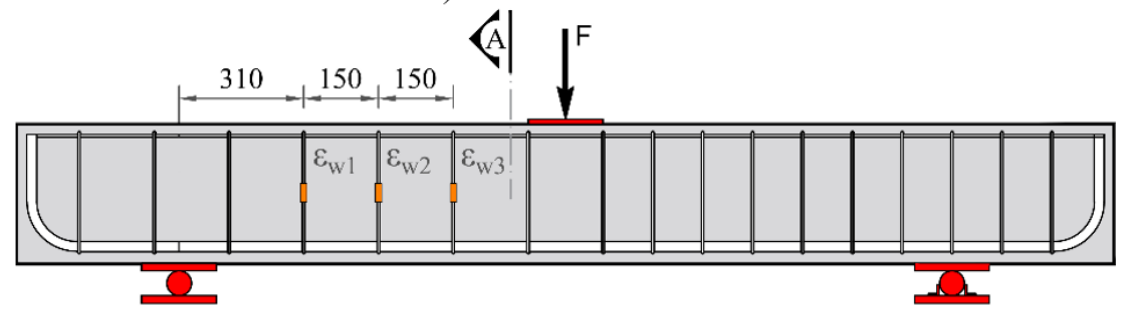

c) Strains in the shear reinforcement
Section A-A

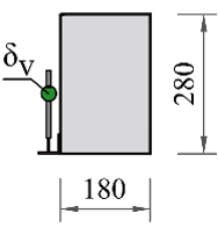

Section A-A

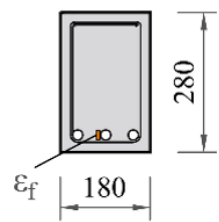

Section A-A

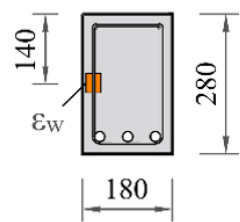

Figure 4. Instrumentation of the tested beams. 


\subsection{Shear strength of beams according to ABNT NBR 6118}

ABNT NBR 6118 [11] considers that the shear strength of a beam $\left(\mathrm{V}_{\mathrm{R}}\right)$ can be computed as the sum of the contributions given by the concrete shear resistant mechanisms $\left(V_{\mathrm{Rc}}\right)$ and the steel activated up to failure $\left(V_{\mathrm{Rs}}\right)$, as expressed in Equation 1. The Brazilian code presents two different models to calculate the contributions from concrete $\left(V_{\mathrm{Rc}}\right)$, shear reinforcement $\left(V_{\mathrm{Rs}}\right)$, and the maximum resistance due to concrete strut's crushing $\left(V_{\mathrm{Rmax}}\right)$. Model I assume that the concrete struts have an angle of $\theta=45^{\circ}$, and the shear strength can be calculated considering Equations 1-4. Model II admits that the concrete strut angle can vary between $30^{\circ}$ to $45^{\circ}$ in relation to the beam's longitudinal axis. Thus, the shear strength can be obtained by using Equation 1 and Equations 5-7.

$V_{R}=V_{R c}+V_{R s} \leq V_{R, \max }$

$V_{R c, I}=0.6 \cdot f_{c t d} \cdot b_{w} \cdot d$

$V_{R s, I}=\frac{A_{s w}}{s} 0.9 \cdot d \cdot f_{y w d} \cdot(\operatorname{sen} \alpha+\cos \alpha)$

$V_{R, \max I}=0.27 \cdot\left(1-\frac{f_{c k}}{250}\right) \cdot f_{c k} \cdot b_{w} \cdot d$

$V_{R c, I I}=V_{R c, I} \cdot \frac{V_{R, \text { máxII }}-V}{V_{R, \max x I}-V_{R c, I}} \leq V_{R c, I}$

$V_{R s w, I I}=\frac{A_{s w}}{s} 0.9 \cdot d \cdot f_{y w} \cdot(\cot \alpha+\cot \theta) \cdot \operatorname{sen} \alpha$

$V_{R, \text { máxII }}=0.54 \cdot\left(1-\frac{f_{c k}}{250}\right) \cdot f_{c k} \cdot b_{w} \cdot d \cdot \operatorname{sen}^{2} \cdot(\cot \alpha+\cot \theta)$

Where:

$b_{\mathrm{w}}$ is the smallest cross-sectional width; $d$ is the effective depth of the beam; $s$ is the spacing of the stirrups; $f_{c t d}=\frac{f_{c t k, i n f}}{\gamma_{c}}$ $; f_{c t k, i n f}=0.7 \cdot f_{c t m} ; f_{c t m}=0.3 \cdot f_{c}^{2 / 3}$ for concrete strength class varying from C20 to C50; $f_{c t m}=2.12 \ln \left(1+0,11 \cdot f_{c k}\right)$ for concrete $\mathrm{C} 55$ until C90; $f_{y w}$ is the yield strength of the shear reinforcement, limited to $500 \mathrm{MPa}$ in this paper.

\subsection{Database}

A database containing results of shear tests on reinforced concrete beams with the replacement of NCA by RCA. An extensive literature review was carried, and the following criteria were considered during the selection of the test results:

a) Only beams with shear span-to-depth ratio $(a / d)$ greater than or equal to 2.5 were used, restricting the analyses and conclusions of this study to the case of slender beams;

b) Only beams made of concrete with compressive strength ranging from $20 \mathrm{MPa}$ to $90 \mathrm{MPa}$ were used to respect the scope of the ABNT NBR 6118 [11];

c) Only beams with $\rho \mathrm{l}$ and $\rho$ w within the minimum and maximum limits prescribed by ABNT NBR 6118 [11] were used. Following these ideas, a database with 170 beams (see Annex A) was developed. For the analyses and discussions, these beams were classified into three groups:

a) Group 1 contained beams with NCA to RCA replacement rates of less than $11 \%$. There were 22 beams without shear reinforcement and 20 beams with closed stirrups; 
b) Group 2 had beams with RCA replacement rates ranging from $11 \%$ to $50 \%$. There were 32 beams without stirrups and 20 beams with stirrups.

c) Group 3 had beams with RCA replacement rates greater than $50 \%$. There were 46 beams without shear reinforcement and 30 beams with stirrups.

This database, formed by results from tests presented in references [4], [5], [6], [16], [19], [20], [25], [26], [27], [28], [29], [30], [31] and [32], allows a comprehensive evaluation of the influence of the values of $\rho_{\mathrm{l}}, \rho_{\mathrm{w}}$, and the NCA to RCA replacement on the shear strength of reinforced concrete beams.

\section{RESULTS AND DISCUSSION}

\subsection{Experimental tests}

Tests on cylindrical specimens, $100 \mathrm{~mm}$ of diameter and $200 \mathrm{~mm}$ of length, were performed to determine the compressive strength of concrete, following the recommendations of the ABNT NBR 5739 [33]. Diametral compression tests on $100 \times 200 \mathrm{~mm}$ cylindrical specimens were carried to determine the concrete's tensile strength, following the recommendations of the ABNT NBR 7222 [34]. The modulus of elasticity of the concrete was also measured, following the recommendations of ABNT NBR 8522 [35], in tests on cylindrical specimens with $150 \mathrm{~mm}$ of diameter and $30 \mathrm{~mm}$ of height.

The concrete's compressive and tensile strength's presented values represent the highest strength measured in a pair of specimens. For the modulus of elasticity, the results presented are the mean of the results obtained in three cylindric samples. The results of the characterization tests are presented in Figure 5.

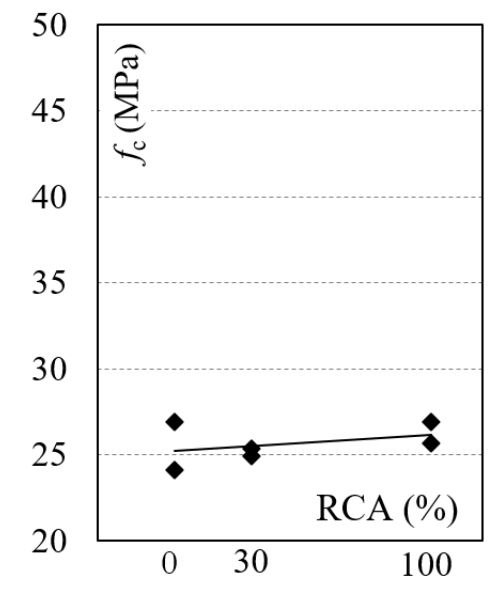

a) Compressive strength

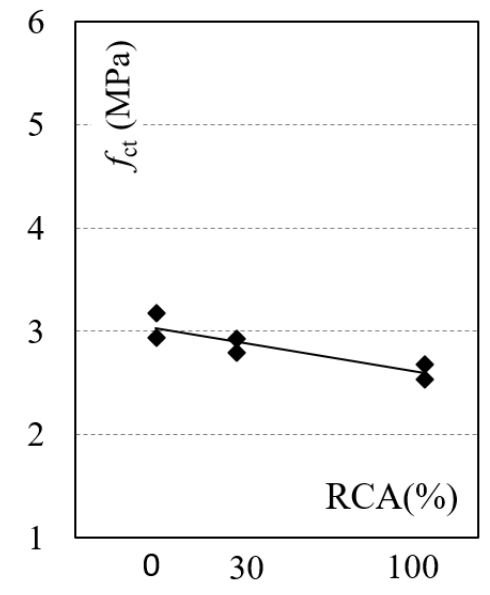

b) Tensile strength

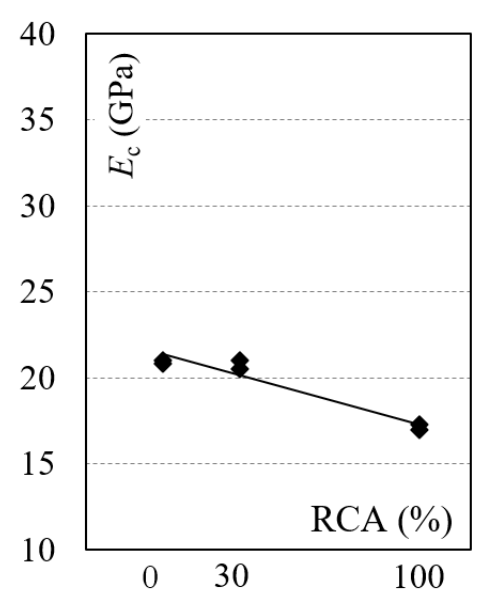

c) Modulus of elasticity

Figure 5 - Results of characterization tests.

The compressive strength results show that the concrete proportioning was successful, and the mean resistance was maintained regardless of the replacement ratio of NCA by RCA. The same was not observed for either the tensile strength or the modulus of elasticity of the concrete. Concerning the tensile strength, a reduction trend is noted for both replacement ratios of $30 \%$ and $100 \%$. In general, an average reduction of $15 \%$ was measured in the tensile strength due to $100 \%$ replacement ratio of NCA by RCA. The substitution of $30 \%$ of RCA did not affect the modulus of elasticity results, but a replacement ratio of $100 \%$, an average reduction of $20 \%$ was observed.

Three samples of each rebar size were submitted to axial tensile tests, following the recommendations of ABNT NBR ISO 6892 [36], to obtain the mechanical properties of the flexural and shear reinforcement. These results are summarized in Table 2 and are on the expected range of the steel bars commercialized in Brazil. 
Table 2 - Mechanical properties of reinforcement bars

\begin{tabular}{cccc}
\hline $\boldsymbol{\sigma}(\mathbf{m m})$ & $\boldsymbol{f}_{\mathbf{y s}}(\mathbf{M P a})$ & $\boldsymbol{\varepsilon}_{\mathbf{y s}} \mathbf{\%}$ & $\boldsymbol{E}_{\mathbf{s}}(\mathbf{G P a})$ \\
\hline 4,2 & 610 & 3,02 & 202 \\
\hline 20 & 546 & 2,80 & 194 \\
\hline
\end{tabular}

Figure 6 presents the tested beams' response, measured by the relation between the applied shear force $(V)$ and the vertical displacements $(\delta)$ in mid-spam. The behaviour of the beams without shear reinforcement was fragile, and the shear failure occurred abruptly, with low displacement levels. For these beams, it was not observed relevant reductions of their flexural stiffness due to the replacement of the NCA by RCA. The beams with shear reinforcement reached significantly higher loading levels before the ruin, allowing the observation of a reduction in flexural stiffness due to the replacement of NCA by RCA.

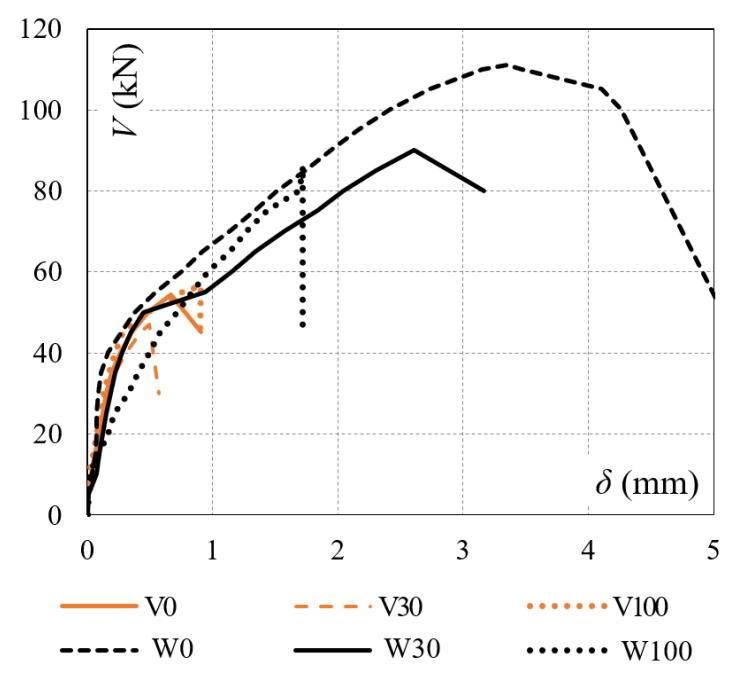

Figure 6 $-V-\delta$ response of the tested beams.

Table 3 shows the beams' measured strengths and compares the experimental results with theoretical predictions using models I and II from [11]. For beams without shear reinforcement, a significant reduction of the shear resistance was observed with the replacement of $30 \%$ of NCA by RCA. The same was not observed for a $100 \%$ replacement ratio, as V100 strength was almost the same as the reference beam (V0). For tests on beams with stirrups, a trend of strength reductions was experimentally observed. The substitution of NCA by RCA led to a $19 \%$ reduction of the shear strength of beam $\mathrm{W} 30$ and $22 \%$ for beam $\mathrm{W} 100$.

Table 3 - Experimental relations with design codes.

\begin{tabular}{|c|c|c|c|c|c|}
\hline \multicolumn{2}{|c|}{ Experimental values } & \multicolumn{2}{|c|}{$V_{\text {Res }}(\mathbf{k N})$} & \multirow{2}{*}{$V_{\mathbf{u}} / \boldsymbol{V}_{\text {Rcs.I }}$} & \multirow{2}{*}{$V_{\mathbf{u}} / \boldsymbol{V}_{\text {Res.II }}$} \\
\hline Beams & $V_{\mathrm{u}}(\mathrm{KN})$ & I & II & & \\
\hline V0 & 54.33 & 53.6 & 53.6 & 1.01 & 1.01 \\
\hline V30 & 46.74 & 53.7 & 53.7 & 0.87 & 0.87 \\
\hline V100 & 56.57 & 58.6 & 58.6 & 0.96 & 0.96 \\
\hline W0 & 110.97 & 76.6 & 83.9 & 1.45 & 1.32 \\
\hline W30 & 90.07 & 72.3 & 79.3 & 1.25 & 1.14 \\
\hline \multirow[t]{4}{*}{ W100 } & 86.08 & 73.4 & 80.5 & 1.17 & 1.07 \\
\hline & Mean & & & 1.12 & 1.06 \\
\hline & SD & & & 0.21 & 0.16 \\
\hline & $\operatorname{COV}(\%)$ & & & 19.11 & 14.75 \\
\hline
\end{tabular}


Figure 7 graphically presents the ratio between the experimentally measured shear strengths $\left(V_{\mathrm{u}}\right)$ and the theoretical results obtained according to NBR 6118 [11] $\left(\mathrm{V}_{\text {Rcs,I, }}\right.$ and $\left.\mathrm{V}_{\mathrm{Rcs}, \mathrm{II}}\right)$. In Figure 7, the tests on beams without shear reinforcement reveal that the theoretical models overestimate the concrete contribution in the shear strength, regardless of the replacement ratio of NCA by RCA. On the other hand, for beams with stirrups, the theoretical models presented by NBR 6118 [11] produced conservative estimates of the shear strength, even for beams with RCA, with model II presenting a better correlation between the estimates and theoretical results. It should also be highlighted that the theoretical calculations' safety levels decreased within the increase of the RCA content.
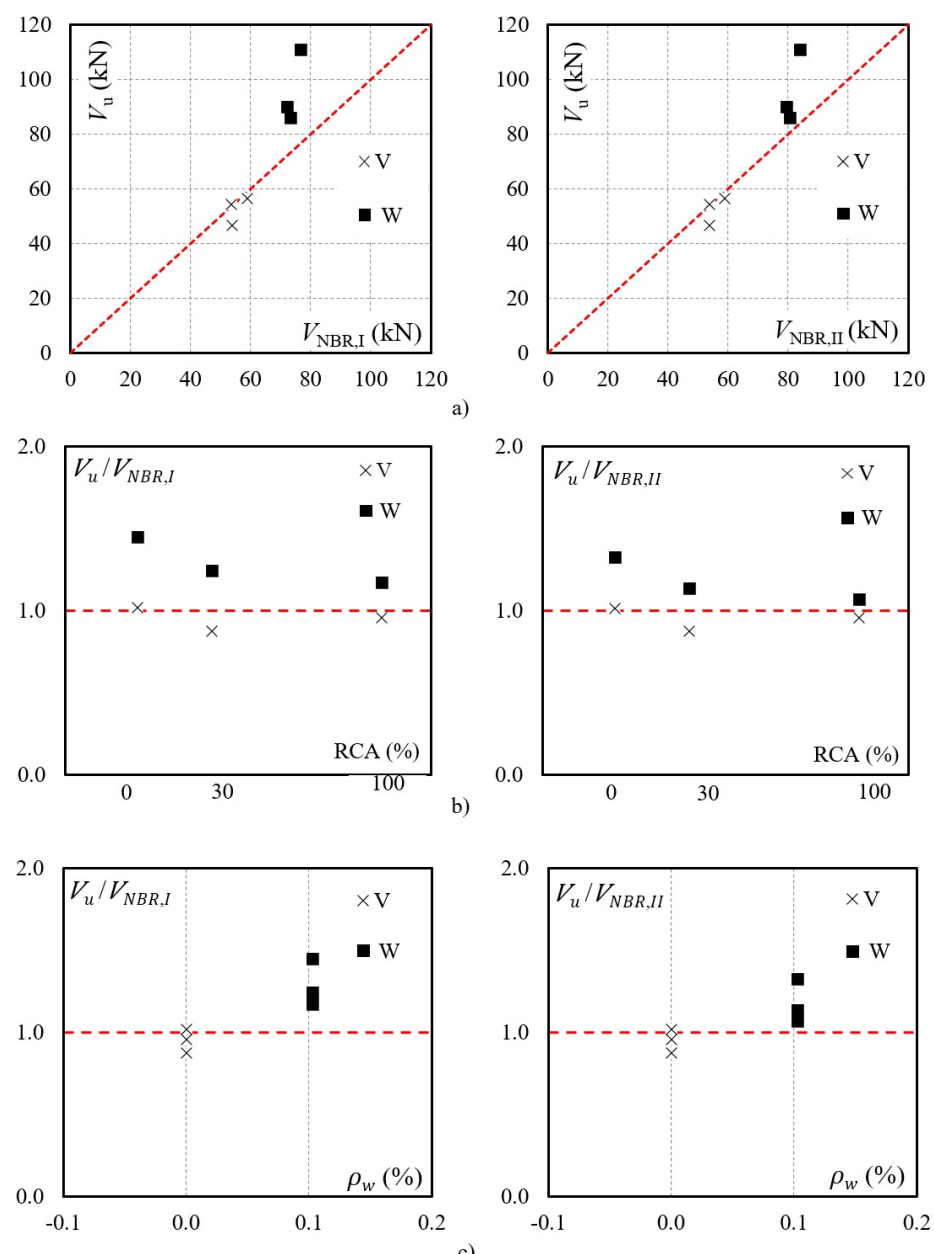

Figure 7 - Comparison between the experimental and theoretical for the tested beams.

\subsection{Database}

Figure 8 presents comparisons between the experimental shear strengths $\left(V_{\mathrm{u}}\right)$ and the theoretical estimates obtained using models I and II ( $V_{\mathrm{NBR}, \mathrm{I}}$ and $\left.V_{\mathrm{NBR}, \mathrm{II}}\right)$ from [11] for the beams with shear reinforcement. These analyses are carried in general terms in Figure 8a and as a function of the percentage of replacement of NCA by RCA (Figure 8b) and the flexural and shear reinforcement ratio (Figures 8c and 8d). Figure 8a shows that, for both models, most of the theoretical estimates were conservative.

Figures $8 \mathrm{~b}, 8 \mathrm{c}$, and $8 \mathrm{~d}$ evidence that, regardless of the replacement percentage of NCA by RCA, the safety of the theoretical estimates, measured by the ratio between experimental and theoretical results, is mainly affected by the flexural reinforcement ratio of the beams. In this context, if any adjustments in NBR 6118 [11] would have to be recommended, they would not be motivated by using recycled concrete aggregates instead of natural coarse aggregates.

Similar analyses are carried in Figure 9 but considering the results of tests on beams without shear reinforcement. These analyses are carried to check the performance of the theoretical models presented by NBR 6118 [11] to account for the 
contribution of concrete to the shear resistance of reinforced concrete beams and if this performance is affected by the replacement of natural coarse aggregates by recycled concrete aggregates. In general, the dispersion between experimental and theoretical estimates is significantly smaller in this situation (see Figure 9a). However, for a significant number of results, the theoretical models overestimate the shear resistance of the tested beams. No correlation between the replacement ratio of NCA by RCA is observed (see Figure 9b), and the safety level of the theoretical estimates slightly increases with the growth of the flexural reinforcement ratio of the beams, regardless of the use or not of recycled concrete aggregates.

Table 4 evaluates the performances of theoretical models according to the Demerit Points Classification (DPC) proposed by Collins [37]. For beams with shear reinforcement (see Figure 10a), the model I from [11] showed better performance, with $80 \%$ of results falling into the appropriate safety and conservative classes. The worst performance from model II resulted from $18 \%$ of their results being classified in the dangerous class. Considering the results of beams without shear reinforcement, both models had similar performance, as shown in Figure 10b.
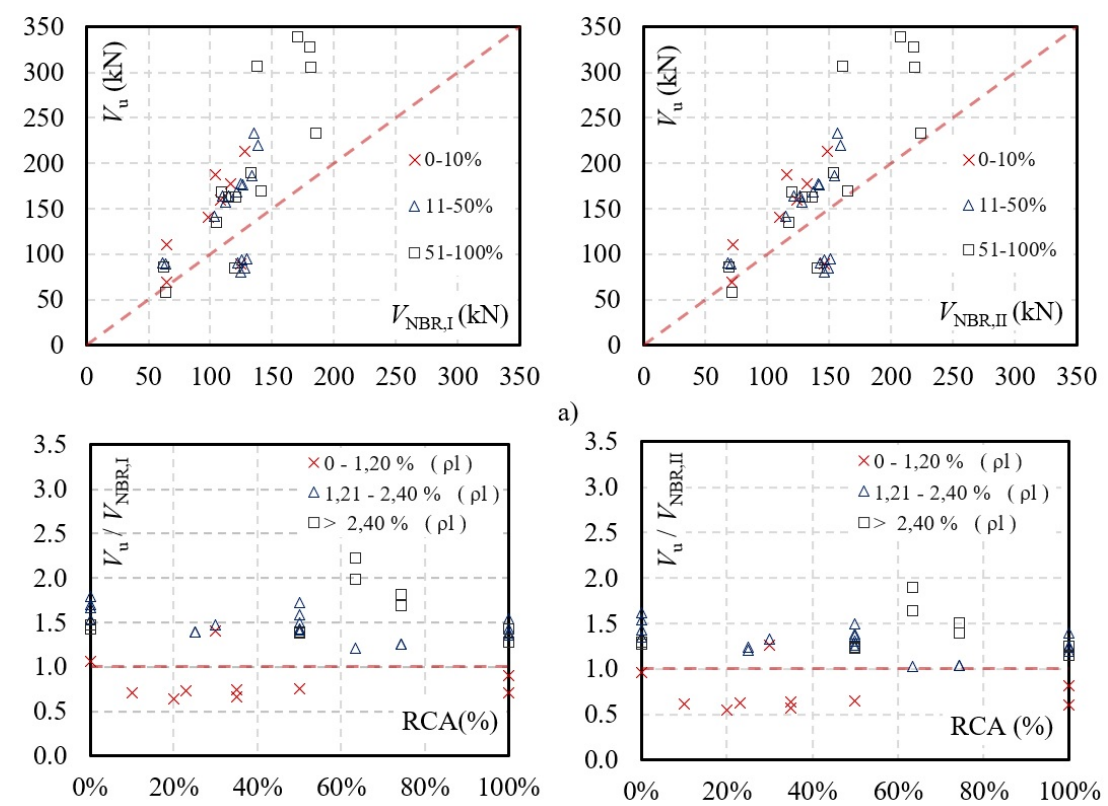

b)
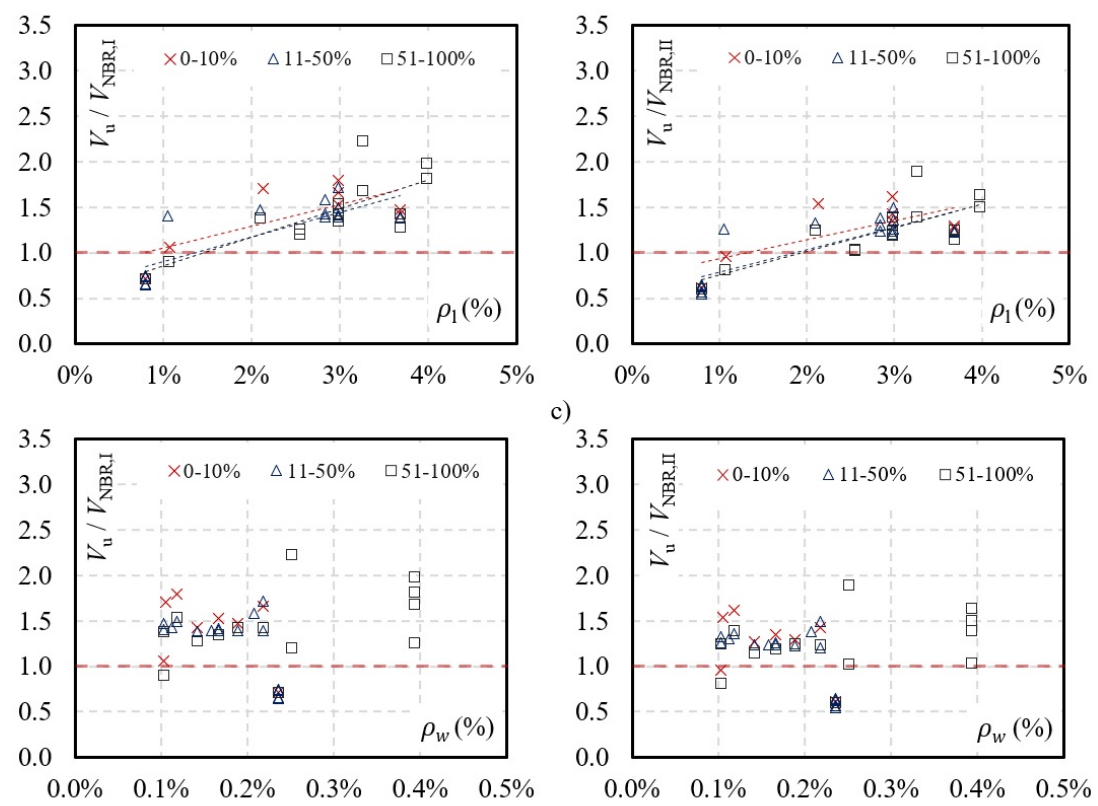

$$
\text { d) }
$$

c)

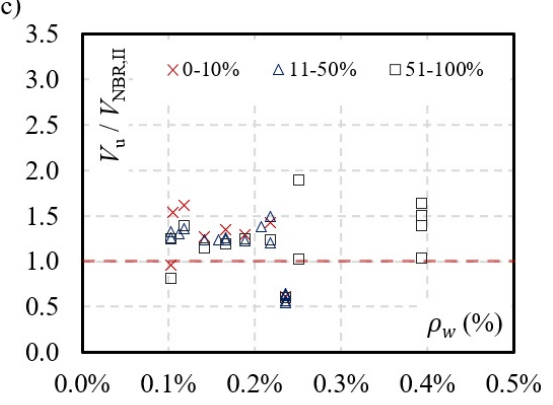

Figure 8. Comparison between the experimental and theoretical for the database of beams with stirrups 

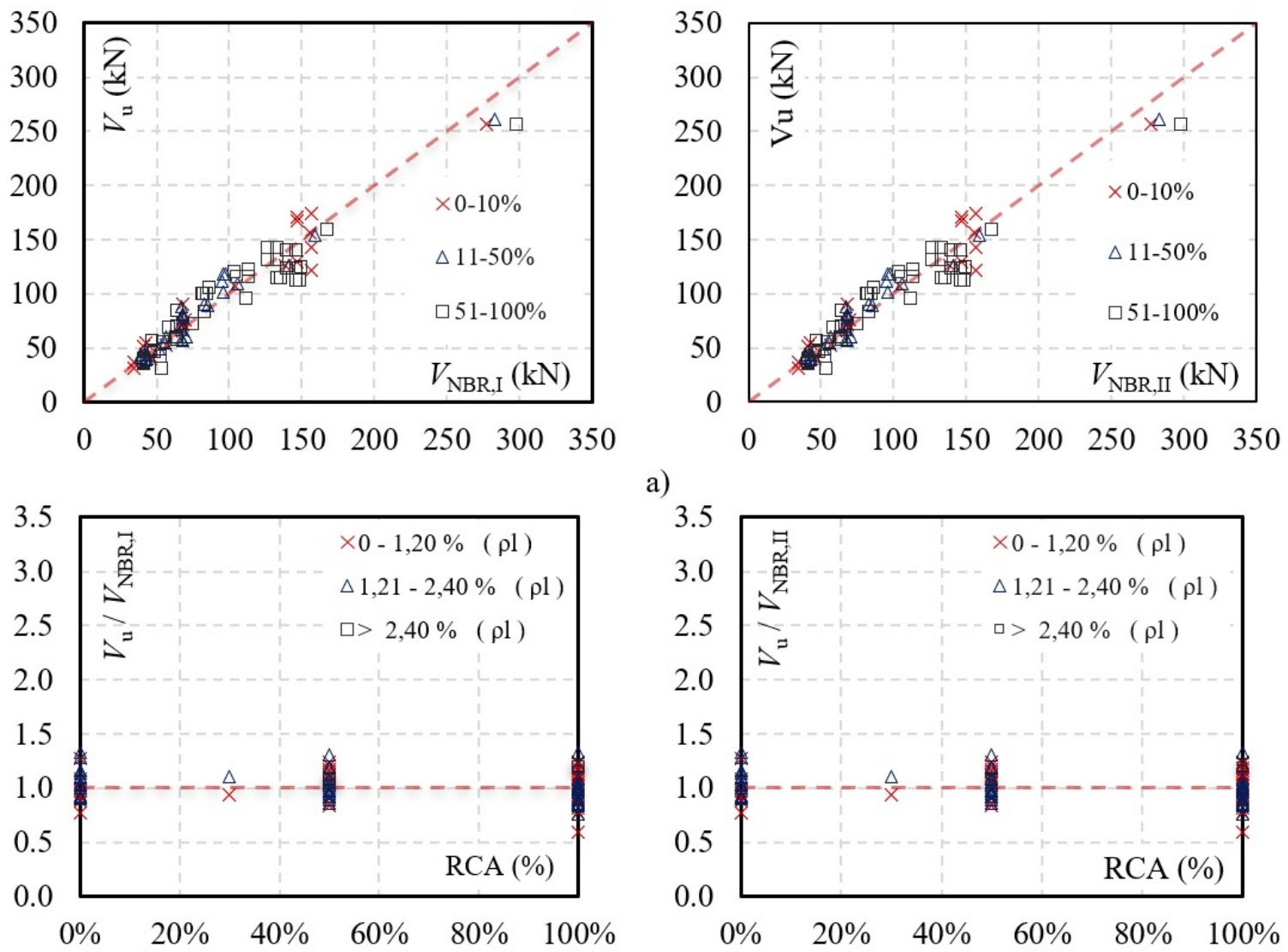

a)

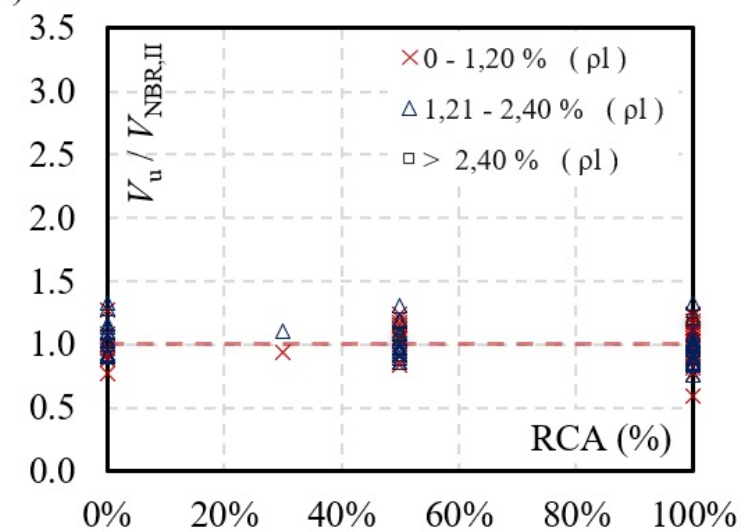

b)
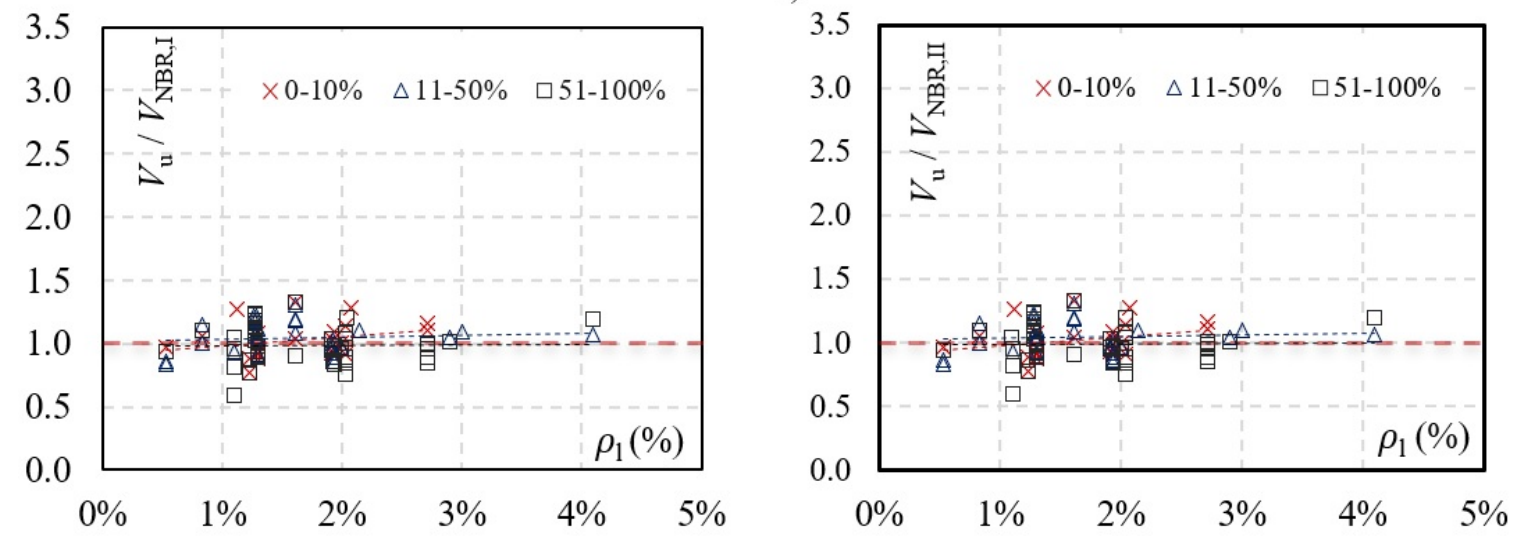

c)

Figure 9. Comparison between the experimental and theoretical for the database of beams without stirrups

Table 4. Performance of theoretical estimates as proposed by Collins [37].

\begin{tabular}{ccc}
\hline $\boldsymbol{V}_{\mathbf{u}} / \boldsymbol{V}_{\text {teo }}$ & Score & Classification \\
\hline$<0.50$ & 10 & Extremely dangerous \\
\hline $0.50-0.65[$ & 5 & Dangerous \\
\hline $0.65-0.85[$ & 2 & Low safety \\
\hline $0.85-1.30[$ & 0 & Appropriate safety \\
\hline$[1.30-2.00[$ & 1 & Conservative \\
\hline$\geq 2.00$ & 2 & Overconservative \\
\hline
\end{tabular}



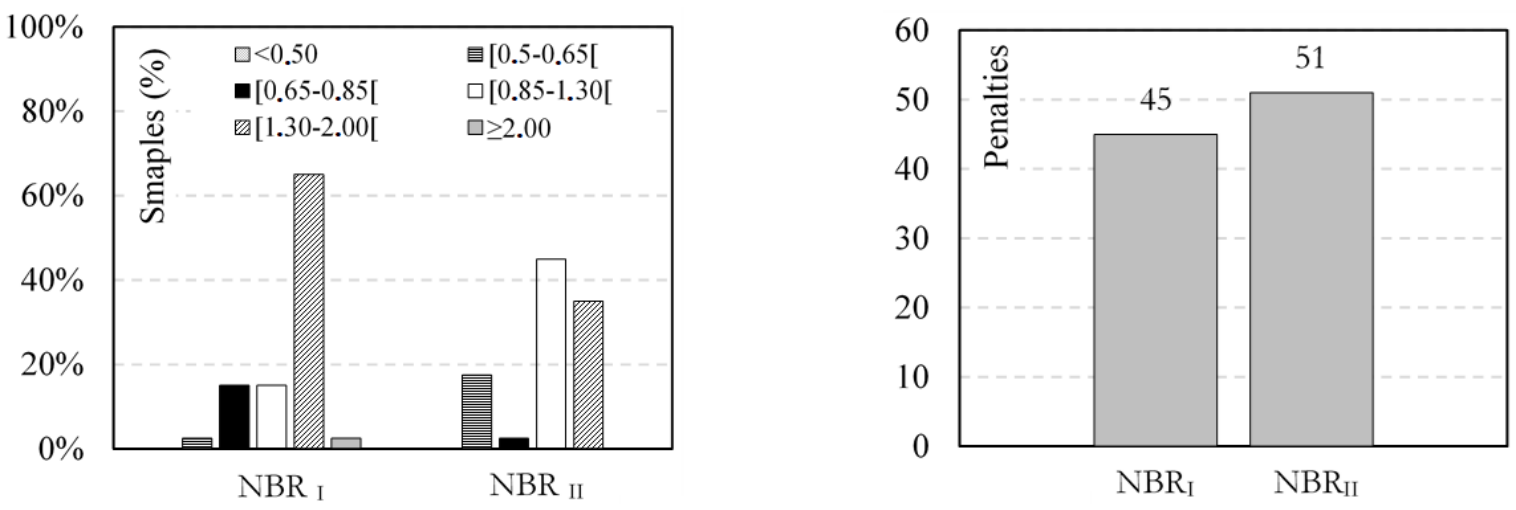

a) Beams with shear reinforcement.
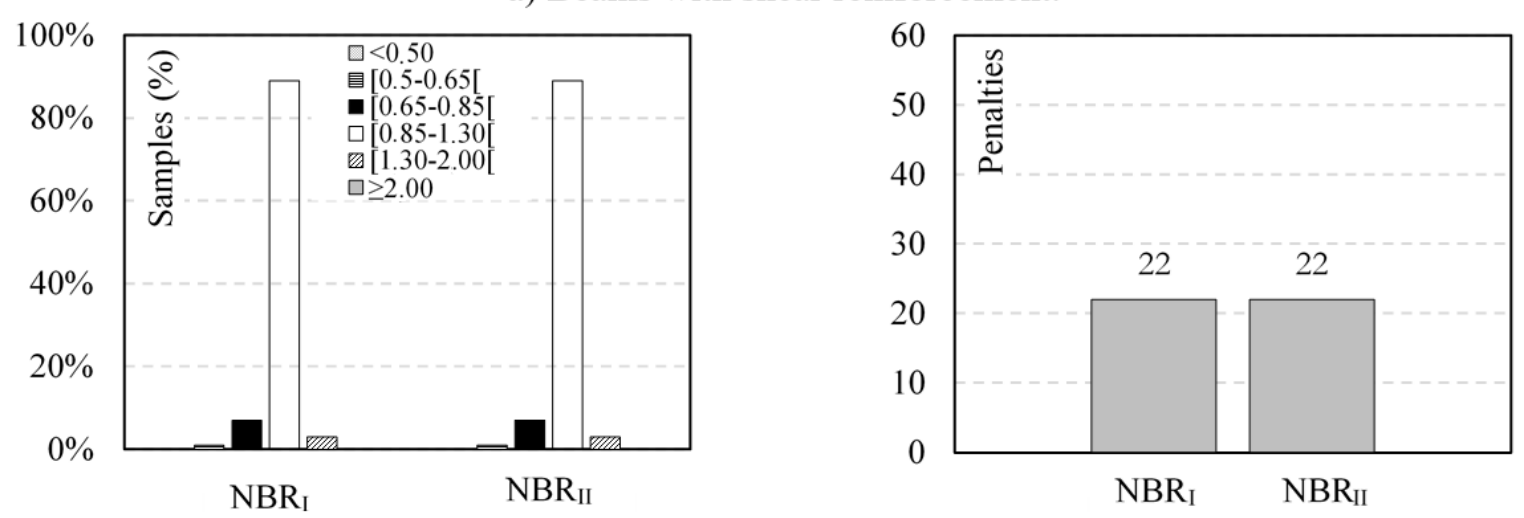

b) Beams without shear reinforcement.

Figure 10. Result of the DPC for the beams within the database.

\section{CONCLUSIONS}

The main conclusions obtained were:

- The replacement of natural coarse aggregates by recycled concrete aggregates was not associated with reductions in concrete's compressive strength, considering the materials and the concrete proportioning used in the experimental program.

- The concrete's tensile strength and modulus of elasticity were slightly affected by the substitution of natural aggregates by recycled concrete aggregates. For the tensile strength, an average reduction of $15 \%$ was measured, and for the modulus of elasticity, mean reductions of $20 \%$ were observed, both for $100 \%$ replacement of NCA by RCA.

- Small reductions in the flexural stiffness and the shear resistance were observed in the tested beams due to the replacement of NCA by RCA. Those with shear reinforcement showed a conservative correlation between experimental and theoretical resistance estimates. On the other hand, those without shear reinforcement presented ultimate shear capacity below the theoretical expectation, regardless of the replacement of NCA by RCA.

- The extensive analyses allowed by the database with tests on beams without and with shear reinforcement do not show significant shear strength reductions associated with the substitution of natural coarse aggregates by recycled concrete aggregates. Considering the safety levels of the theoretical shear strengths obtained by following models I and II from the Brazilian code, these analyses show that the unsafe predictions are not associated with the use of recycled concrete aggregates but with the consideration of the contribution given by the flexural reinforcement ratio of the reinforced concrete beams. 


\section{REFERENCES}

[1] W. H. Langer, L. J. Drew, and J. S. Sachs. Aggregate and the Environment. American Geoological Institute, 2004.

[2] T. P. Pinto, "Metodologia para a gestão diferenciada de resíduos sólidos da construção urbana," Ph.D. dissertation, Esc. Politéc., Univ. São Paulo, 2009.

[3] Associação Brasileira das Empresas de Limpeza Pública e Resíduos Especiais, Panorama dos Resíduos Sólidos no Brasil 2018/2019, 2019. [Online]. Available: http://abrelpe.org.br/download-panorama-2018-2019/

[4] M. Arezoumandi, J. Drury, J. S. Volz, and K. H. Khayat, "Effect of recycled concrete aggregate replacement level on shear strength of reinforced concrete beams," ACI Mater. J., vol. 112, no. 4, 2015.

[5] K. N. Rahal and Y. T. Alrefaei, "Shear strength of longitudinally reinforced recycled aggregate concrete beams," Eng. Struct., vol. 145, pp. 273-282, 2017.

[6] I. S. Ignjatović, S. B. Marinković, and N. Tošić, "Shear behaviour of recycled aggregate concrete beams with and without shear reinforcement," Eng. Struct., vol. 141, pp. 386-401, 2017.

[7] H. P. J. Taylor. Investigation of the Forces Carried Across Cracks in Reinforced Concrete Beams in Shear by Interlock of Aggregate. Cement and Concrete Association, 1970.

[8] S. D. Poli, M. di Prisco, and P. G. Gambarova, "Cover and stirrup effects on the shear response of Dowel bar embedded in concrete," ACI Struct. J., vol. 90, pp. 441-450, 1993. http://dx.doi.org/10.14359/3962.

[9] T. Ulaga, "Reinforced concrete elements with reinforcement composed of bars and strips: bond and tension modelling," M.S. thesis, ETHZ, Zurich, 2003.

[10] J. Sagaseta and R. L. Vollum, "Influence of aggregate fracture on shear transfer through cracks in reinforced concrete," Mag. Concr. Res., vol. 63, no. 2, pp. 119-137, 2011.

[11] Associação Brasileira de Normas Técnicas, Projeto de Estruturas de Concreto - Procedimento, NBR 6118, 2014.

[12] S. W. Tabsh and A. S. Abdelfatah, "Influence of recycled concrete aggregates on strength properties of concrete," Constr. Build. Mater., vol. 23, no. 2, pp. 1163-1167, 2009.

[13] M. J. McGinnis, M. Davis, A. De La Rosa, B. D. Weldon, and Y. C. Kurama, "Quantified sustainability of recycled concrete aggregates," Mag. Concr. Res., vol. 69, no. 23, pp. 1203-1211, 2017., http://dx.doi.org/10.1680/jmacr.16.00338.

[14] N. K. Bairagi, K. Ravande, and V. K. Pareek, "Behaviour of concrete with different proportions of natural and recycled aggregates," Resour. Conserv. Recycling, vol. 9, no. 1, pp. 109-126, 1993.

[15] K. Yanagibashi, K. Inoue, S. Seko, and D. Tsuji, “A study on cyclic use of aggregate for structural concrete,” in SB05 Tokyo: Action for Sustainability, 2005.

[16] S. Schubert, C. Hoffmann, A. Leemann, K. Moser, and M. Motavalli, "Recycled aggregate concrete: experimental shear resistance of slabs without shear reinforcement," Eng. Struct., vol. 41, pp. 490-497, 2012.

[17] L. N. P. Cordeiro, A. B. Masuero, D. C. C. D. Molin, P. S. L. Souza, and I. N. L. Paes, "Avaliação de processos de misturas de concretos com agregados graúdos reciclados," Ambient. Constr., vol. 17, no. 3, pp. 255-265, 2017.

[18] M. Arezoumandi, A. Smith, J. S. Volz, and K. H. Khayat, "An experimental study on shear strength of reinforced concrete beams with 100\% recycled concrete aggregate," Constr. Build. Mater., vol. 53, pp. 612-620, 2014.

[19] H. B. Choi, C. K. Yi, H. H. Cho, and K. I. Kang, "Experimental study on the shear strength of recycled aggregate concrete beams," Mag. Concr. Res., vol. 62, no. 2, pp. 103-114, 2010.

[20] B. González-Fonteboa and F. Martínez-Abella, "Shear strength of recycled concrete beams," Constr. Build. Mater., vol. 21, no. 4, pp. 887-893, 2007.

[21] Associação Brasileira de Normas Técnicas, Agregados - Determinação da Composição Granulométrica, NBR NM $248,2003$.

[22] M. B. Leite, "Avaliação de propriedades mecânicas de concretos produzidos com agregados reciclados de resíduos de construção e demolição,” Ph.D. dissertation, Univ. Fed. Rio Gd. do Sul, Porto Alegre, 2001.

[23] I. L. Santos, F. S. Salgado Neto, L. H. S. Martins, and L. N. P. Cordeiro, "Dosagem de concretos produzidos com agregado graúdo reciclado de concreto," in An. 57 Cong. Bras. Concr., 2015.

[24] Associação Brasileira de Normas Técnicas, Concreto - Determinação da Consistência pelo Abatimento do Tronco de Cone, NBR NM 67, 1998.

[25] M. Etxeberria Larrañaga, "Experimental study on microstructure and structural behaviour of recycled aggregate concrete,” M.S. thesis, Univ. Politècnica Catalunya, Barcelona, 2004.

[26] A. C. Cardoso, "Efeito da adição de agregados reciclados na resistência ao cisalhamento de vigas de concreto armado," M.S. thesis, Univ. Fed. Pará, Belém, 2018.

[27] G. Fathifazl, A. G. Razaqpur, O. B. Isgor, A. Abbas, B. Fournier, and S. Foo, "Shear strength of reinforced recycled concrete beams with stirrups," Mag. Concr. Res., vol. 62, no. 10, pp. 685-699, 2010., http://dx.doi.org/10.1680/macr.2010.62.10.685. 
[28] A. M. Knaack and Y. C. Kurama, "Behavior of reinforced concrete beams with recycled concrete coarse aggregates," J. Struct. Eng., vol. 141, no. 3, 2015.

[29] H. Katkhuda and N. Shatarat, "Shear behavior of reinforced concrete beams using treated recycled concrete aggregate," Constr. Build. Mater., vol. 125, pp. 63-71, 2016., http://dx.doi.org/10.1016/j.conbuildmat.2016.08.034.

[30] S. W. Kim, C. Y. Jeong, J. S. Lee, and K. H. Kim, "Size effect in shear failure of reinforced concrete beams with recycled aggregate," J. Asian Archit. Build. Eng., vol. 12, no. 2, pp. 323-330, 2013.

[31] S. Sadati, M. Arezoumandi, K. H. Khayat, and J. S. Volz, "Shear performance of reinforced concrete beams incorporating recycled concrete aggregate and high-volume fly ash," J. Clean. Prod., vol. 115, pp. 284-293, 2016.

[32] I. Ignjatović "Ultimate strength of reinforced recycled concrete beams," PhD thesis, Univ. of Belgrade, Belgrade, 2013.

[33] Associação Brasileira de Normas Técnicas, Concreto - Ensaio de Compressão de Corpos de Prova Cilindricos, NBR $5739,2007$.

[34] Associação Brasileira de Normas Técnicas, Concreto e Argamassa - Determinação da Resistência à Tração por Compressão Diametral de Corpos de Prova Cilíndrico, NBR 7222, 2011.

[35] Associação Brasileira de Normas Técnicas, Concreto - Determinação do Módulo Estático de Elasticidade à Compressão, NBR $8522,2008$.

[36] Associação Brasileira de Normas Técnicas, Materiais Metálicos - Ensaio de Tração. Parte 1: Método de Ensaio à Temperatura Ambiente, NBR ISO 6892, 2013.

[37] M. P. Collins, Evaluation of Shear Design Procedures for Concrete Structures. CSA Technical Committee on Reinforced Concrete Design, 2001.

Authors contribution: CARDOSO, C. A: conceptualization, data analysis, bibliographic research, experimental analysis; LIMA, I. G.: experimental analysis, conceptualization, methodology, drafting; FERREIRA, M. P.: conceptualization, supervision, drafting and formal analysis, SOUZA, R. A.: writing and formal analysis.

Editors: Jose Tadeu Balbo, José Luiz Antunes de Oliveira e Sousa, Guilherme Aris Parsekian. 
ANNEX A

Table A1. Database of tests on reinforced concrete beams with shear reinforcement.

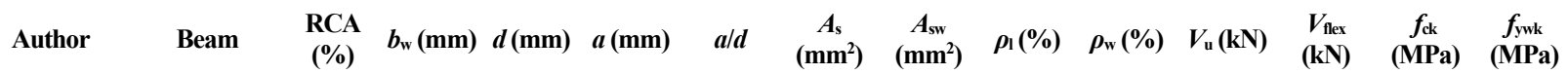

\begin{tabular}{|c|c|c|c|c|c|c|c|c|c|c|c|c|c|c|}
\hline \multirow{3}{*}{ Larrañaga [25] } & $\mathrm{HC}-2$ & 0 & 200 & 304 & 1.000 & 3,3 & 1.810 & 57 & 3,0 & 0,2 & 213 & 214 & 32 & 495 \\
\hline & HC-3 & 0 & 200 & 304 & 1.000 & 3,3 & 1.810 & 57 & 3,0 & 0,2 & 177 & 214 & 32 & 495 \\
\hline & $\mathrm{HC}-4$ & 0 & 200 & 304 & 1.000 & 3,3 & 1.810 & 57 & 3,0 & 0,1 & 188 & 214 & 32 & 495 \\
\hline \multirow{2}{*}{ Cardoso [26] } & VAW0 & 0 & 180 & 254 & 620 & 2,4 & 491 & 28 & 1,1 & 0,1 & 69 & 98 & 23 & 554 \\
\hline & VBW0 & 0 & 180 & 255 & 620 & 2,5 & 942 & 28 & 2,1 & 0,1 & 111 & 166 & 23 & 554 \\
\hline \multirow{2}{*}{$\begin{array}{c}\text { Ignjatović et al. } \\
{[6]}\end{array}$} & NAC-2 & 0 & 200 & 261 & 1.000 & 3,8 & 1.923 & 57 & 3,7 & 0,1 & 141 & 214 & 35 & 391 \\
\hline & NAC-3 & 0 & 200 & 261 & 1.000 & 3,8 & 1.923 & 57 & 3,7 & 0,2 & 160 & 214 & 35 & 391 \\
\hline \multirow{3}{*}{$\begin{array}{l}\text { Rahal and } \\
\text { Alrefaei [5] }\end{array}$} & $35-\mathrm{A}-0-10$ & 10 & 150 & 388 & 1.162 & 3,0 & 462 & 57 & 0,8 & 0,2 & 89 & 94 & 30 & 455 \\
\hline & $35-A-0-20$ & 20 & 150 & 388 & 1.162 & 3,0 & 462 & 57 & 0,8 & 0,2 & 80 & 94 & 30 & 455 \\
\hline & $35-\mathrm{S}-0-23(50)$ & 23 & 150 & 388 & 1.162 & 3,0 & 462 & 57 & 0,8 & 0,2 & 95 & 95 & 33 & 455 \\
\hline \multirow{2}{*}{ Larrañaga [25] } & HR25-2 & 25 & 200 & 304 & 1.000 & 3,3 & 1.810 & 57 & 3,0 & 0,2 & 187 & 220 & 35 & 495 \\
\hline & HR25-3 & 25 & 200 & 304 & 1.000 & 3,3 & 1.810 & 57 & 3,0 & 0,2 & 169 & 220 & 35 & 495 \\
\hline \multirow{2}{*}{ Cardoso [26] } & VAW30 & 30 & 180 & 260 & 620 & 2,4 & 491 & 28 & 1,0 & 0,1 & 89 & 99 & 21 & 554 \\
\hline & VBW30 & 30 & 180 & 250 & 620 & 2,5 & 942 & 28 & 2,1 & 0,1 & 90 & 158 & 21 & 554 \\
\hline \multirow{3}{*}{$\begin{array}{l}\text { Rahal and } \\
\text { Alrefaei [5] }\end{array}$} & $35-\mathrm{A}-0-35$ & 35 & 150 & 388 & 1.162 & 3,0 & 462 & 57 & 0,8 & 0,2 & 90 & 94 & 29 & 455 \\
\hline & $35-S-0-35(75)$ & 35 & 150 & 388 & 1.162 & 3,0 & 462 & 57 & 0,8 & 0,2 & 85 & 94 & 32 & 455 \\
\hline & $35-\mathrm{A}-0-50$ & 50 & 150 & 388 & 1.162 & 3,0 & 462 & 57 & 0,8 & 0,2 & 94 & 94 & 30 & 455 \\
\hline \multirow{3}{*}{$\begin{array}{c}\text { González- } \\
\text { Fonteboa and } \\
\text { Martínez- } \\
\text { Abella [20] }\end{array}$} & V24RC & 50 & 200 & 303 & 1.000 & 3,3 & 1.810 & 57 & 3,0 & 0,1 & 164 & 241 & 35 & 455 \\
\hline & V17RC & 50 & 200 & 303 & 1.000 & 3,3 & 1.810 & 57 & 3,0 & 0,2 & 177 & 245 & 37 & 455 \\
\hline & V13RC & 50 & 200 & 303 & 1.000 & 3,3 & 1.810 & 57 & 3,0 & 0,2 & 234 & 244 & 36 & 455 \\
\hline \multirow{3}{*}{ Larrañaga [25] } & HR50-2 & 50 & 210 & 304 & 1.000 & 3,3 & 1.810 & 57 & 2,8 & 0,2 & 220 & 223 & 35 & 495 \\
\hline & HR50-3 & 50 & 210 & 304 & 1.000 & 3,3 & 1.810 & 57 & 2,8 & 0,2 & 176 & 223 & 35 & 495 \\
\hline & HR50-4 & 50 & 210 & 304 & 1.000 & 3,3 & 1.810 & 57 & 2,8 & 0,1 & 164 & 223 & 35 & 495 \\
\hline \multirow{2}{*}{$\begin{array}{c}\text { Ignjatović et al. } \\
{[6]}\end{array}$} & RAC50-2 & 50 & 200 & 261 & 1.000 & 3,8 & 1.923 & 57 & 3,7 & 0,1 & 142 & 222 & 38 & 391 \\
\hline & RAC50-3 & 50 & 200 & 261 & 1.000 & 3,8 & 1.923 & 57 & 3,7 & 0,2 & 157 & 222 & 38 & 391 \\
\hline \multirow{7}{*}{$\begin{array}{c}\text { Fathifazl et al. } \\
{[27]}\end{array}$} & EM-3S-R & 63,5 & 200 & 309 & 800 & 2,6 & 1.571 & 101 & 2,5 & 0,3 & 170 & 235 & 33 & 482 \\
\hline & EM-6S-R & 63,5 & 200 & 302 & 800 & 2,6 & 1.963 & 101 & 3,3 & 0,3 & 307 & 342 & 33 & 482 \\
\hline & EM-6S-D & 63,5 & 200 & 301 & 800 & 2,7 & 2.395 & 157 & 4,0 & 0,4 & 339 & 374 & 33 & 482 \\
\hline & EV-3S-R & 74,3 & 200 & 309 & 800 & 2,6 & 1.571 & 157 & 2,5 & 0,4 & 233 & 242 & 40 & 482 \\
\hline & EV-3S-R* & 74,3 & 200 & 309 & 800 & 2,6 & 1.571 & 157 & 2,5 & 0,4 & 233 & 242 & 40 & 482 \\
\hline & EV-6S-R & 74,3 & 200 & 302 & 800 & 2,6 & 1.963 & 157 & 3,3 & 0,4 & 306 & 365 & 40 & 482 \\
\hline & EV-6S-D & 74,3 & 200 & 301 & 800 & 2,7 & 2.395 & 157 & 4,0 & 0,4 & 328 & 409 & 40 & 482 \\
\hline $\begin{array}{l}\text { Rahal and } \\
\text { Alrefaei [5] }\end{array}$ & $35-A-0-100$ & 100 & 150 & 388 & 1.162 & 3,0 & 462 & 57 & 0,8 & 0,2 & 85 & 93 & 27 & 455 \\
\hline \multirow{3}{*}{ Larrañaga [25] } & HR100-2 & 100 & 200 & 304 & 1.000 & 3,3 & 1.810 & 57 & 3,0 & 0,2 & 190 & 219 & 34 & 495 \\
\hline & HR100-3 & 100 & 200 & 304 & 1.000 & 3,3 & 1.810 & 57 & 3,0 & 0,2 & 163 & 219 & 34 & 495 \\
\hline & HR100-4 & 100 & 200 & 304 & 1.000 & 3,3 & 1.810 & 57 & 3,0 & 0,1 & 168 & 219 & 34 & 495 \\
\hline \multirow{2}{*}{ Cardoso [26] } & VAW100 & 100 & 180 & 258 & 620 & 2,4 & 491 & 28 & 1,1 & 0,1 & 58 & 99 & 22 & 554 \\
\hline & VBW100 & 100 & 180 & 250 & 620 & 2,5 & 942 & 28 & 2,1 & 0,1 & 86 & 160 & 22 & 554 \\
\hline \multirow{2}{*}{$\begin{array}{c}\text { Ignjatović et al. } \\
{[6]}\end{array}$} & RAC100-2 & 100 & 200 & 261 & 1.000 & 3,8 & 1.923 & 57 & 3,7 & 0,1 & 135 & 225 & 40 & 391 \\
\hline & RAC100-3 & 100 & 200 & 261 & 1.000 & 3,8 & 1.923 & 57 & 3,7 & 0,2 & 163 & 225 & 40 & 391 \\
\hline
\end{tabular}


Table A2. Database of tests on reinforced concrete beams without shear reinforcement.

$\begin{array}{llccccccccc}\text { Author } & \text { Beam } & \begin{array}{c}\mathrm{RCA} \\ (\%)\end{array} & b_{\mathrm{w}}(\mathrm{mm}) & d(\mathrm{~mm}) & a(\mathrm{~mm}) & a / d & A_{\mathrm{s}}\left(\mathrm{mm}^{2}\right) & \rho_{\mathrm{l}}(\%) & V_{\mathrm{u}}(\mathrm{kN}) & V_{\text {flex }}(\mathrm{kN}) f_{\text {ck }}(\mathrm{MPa})\end{array}$

\begin{tabular}{|c|c|c|c|c|c|c|c|c|c|c|c|}
\hline \multirow{4}{*}{ Choi et al. [19] } & NANAC-L2.5 & 0 & 200 & 360 & 900 & 2,5 & 382 & 0,5 & 66 & 75 & 21 \\
\hline & NANAC-M2.5 & 0 & 200 & 360 & 900 & 2,5 & 598 & 0,8 & 72 & 106 & 21 \\
\hline & NANAC-H2.5 & 0 & 200 & 360 & 900 & 2,5 & 1.159 & 1,6 & 91 & 178 & 21 \\
\hline & NANAC-H3.5 & 0 & 200 & 360 & 1.170 & 3,3 & 1.159 & 1,6 & 71 & 137 & 21 \\
\hline \multirow{4}{*}{$\begin{array}{c}\text { Knaackand } \\
\text { Kurama [28] }\end{array}$} & S0-1a & 0 & 150 & 200 & 760 & 3,8 & 390 & 1,3 & 31 & 51 & 27 \\
\hline & S0-1b & 0 & 150 & 200 & 760 & 3,8 & 390 & 1,3 & 37 & 51 & 27 \\
\hline & S0-2a & 0 & 150 & 200 & 760 & 3,8 & 390 & 1,3 & 40 & 54 & 42 \\
\hline & S0-2b & 0 & 150 & 200 & 760 & 3,8 & 390 & 1,3 & 42 & 54 & 42 \\
\hline Katkhuda [29] & $\mathrm{NC}-3$ & 0 & 200 & 267 & 800 & 3,0 & 1.018 & 1,9 & 53 & 130 & 24 \\
\hline \multirow{6}{*}{$\begin{array}{c}\text { Arezoumandi et al. } \\
\text { [4] }\end{array}$} & CC-NS-4.1 & 0 & 300 & 400 & 1.200 & 3,0 & 1.810 & 1,2 & 121 & 228 & 33 \\
\hline & CC-NS-4.2 & 0 & 300 & 400 & 1.200 & 3,0 & 1.810 & 1,2 & 130 & 226 & 30 \\
\hline & CC-NS-6.1 & 0 & 300 & 400 & 1.200 & 3,0 & 1.810 & 2,0 & 143 & 228 & 33 \\
\hline & CC-NS-6.2 & 0 & 300 & 400 & 1.200 & 3,0 & 1.810 & 2,0 & 167 & 226 & 30 \\
\hline & CC-NS-8.1 & 0 & 300 & 400 & 1.200 & 3,0 & 1.810 & 2,7 & 174 & 228 & 33 \\
\hline & CC-NS-8.2 & 0 & 300 & 400 & 1.200 & 3,0 & 1.810 & 2,7 & 171 & 226 & 30 \\
\hline \multirow{5}{*}{ Kim et al. [30] } & NA-S2 & 0 & 200 & 300 & 750 & 2,5 & 1.161 & 1,9 & 76 & 204 & 28 \\
\hline & NA-M2 & 0 & 200 & 450 & 1.125 & 2,5 & 1.734 & 1,9 & 107 & 305 & 28 \\
\hline & NA-L2 & 0 & 200 & 600 & 1.500 & 2,5 & 2.323 & 1,9 & 126 & 408 & 28 \\
\hline & NA-M3 & 0 & 300 & 450 & 1.125 & 2,5 & 2.694 & 2,0 & 157 & 471 & 28 \\
\hline & NA-L4 & 0 & 400 & 600 & 1.500 & 2,5 & 4.645 & 1,9 & 256 & 816 & 28 \\
\hline \multirow{4}{*}{ Cardoso [26] } & VAO & 0 & 180 & 244 & 620 & 2,5 & 491 & 1,1 & 52 & 92 & 20 \\
\hline & VBO & 0 & 180 & 253 & 620 & 2,5 & 942 & 2,1 & 54 & 159 & 20 \\
\hline & VA30 & 30 & 180 & 248 & 620 & 2,5 & 491 & 1,1 & 41 & 95 & 21 \\
\hline & VB30 & 30 & 180 & 245 & 620 & 2,5 & 942 & 2,1 & 47 & 155 & 21 \\
\hline \multirow{8}{*}{ Choi et al. [19] } & RARAC30-L2.5 & 50 & 200 & 360 & 900 & 2,5 & 382 & 0,5 & 57 & 75 & 21 \\
\hline & RARAC30-M2.5 & 50 & 200 & 360 & 900 & 2,5 & 598 & 0,8 & 78 & 106 & 21 \\
\hline & RARAC30-H2.5 & 50 & 200 & 360 & 900 & 2,5 & 1.159 & 1,6 & 81 & 178 & 21 \\
\hline & RARAC30-H3.5 & 50 & 200 & 360 & 1.170 & 3,3 & 1.159 & 1,6 & 81 & 137 & 21 \\
\hline & RARAC50-L2.5 & 50 & 200 & 360 & 900 & 2,5 & 382 & 0,5 & 58 & 75 & 20 \\
\hline & RARAC50-M2.5 & 50 & 200 & 360 & 900 & 2,5 & 598 & 0,8 & 67 & 106 & 20 \\
\hline & RARAC50-H2.5 & 50 & 200 & 360 & 900 & 2,5 & 1.159 & 1,6 & 88 & 178 & 20 \\
\hline & RARAC50-H3.5 & 50 & 200 & 360 & 1.170 & 3,3 & 1.159 & 1,6 & 73 & 137 & 20 \\
\hline $\begin{array}{c}\text { Ignjatovic (2013) } \\
{[32]}\end{array}$ & RAC50-1b & 50 & 200 & 235 & 1.000 & 4,3 & 1.922 & 4,1 & 60 & 160 & 29 \\
\hline \multirow{4}{*}{$\begin{array}{l}\text { Knaackand } \\
\text { Kurama [28] }\end{array}$} & S50-1a & 50 & 150 & 200 & 760 & 3,8 & 390 & 1,3 & 44 & 53 & 38 \\
\hline & S50-1b & 50 & 150 & 200 & 760 & 3,8 & 390 & 1,3 & 39 & 53 & 38 \\
\hline & S50-2a & 50 & 150 & 200 & 760 & 3,8 & 390 & 1,3 & 44 & 53 & 33 \\
\hline & S50-2b & 50 & 150 & 200 & 760 & 3,8 & 390 & 1,3 & 41 & 53 & 33 \\
\hline \multirow{2}{*}{ Katkhuda [29] } & R50-3 & 50 & 200 & 267 & 800 & 3,0 & 1.018 & 1,9 & 49 & 127 & 21 \\
\hline & T50-3 & 50 & 200 & 267 & 800 & 3,0 & 1.018 & 1,9 & 55 & 130 & 24 \\
\hline \multirow{6}{*}{ Sadati et al. [31] } & RAC50-1 & 50 & 200 & 303 & 1.000 & 3,3 & 1.818 & 3,0 & 91 & 237 & 36 \\
\hline & RAC50-2 & 50 & 200 & 303 & 1.000 & 3,3 & 1.757 & 2,9 & 89 & 233 & 37 \\
\hline & RAC50-3 & 50 & 150 & 200 & 760 & 3,8 & 390 & 1,3 & 44 & 51 & 38 \\
\hline & RAC50-4 & 50 & 150 & 200 & 760 & 3,8 & 390 & 1,3 & 39 & 51 & 38 \\
\hline & RAC50-5 & 50 & 150 & 200 & 760 & 3,8 & 390 & 1,3 & 44 & 51 & 33 \\
\hline & RAC50-6 & 50 & 150 & 200 & 760 & 3,8 & 390 & 1,3 & 41 & 51 & 33 \\
\hline \multirow{5}{*}{ Kim et al. [30] } & RH-S2 & 50 & 200 & 300 & 750 & 2,5 & 1.161 & 1,9 & 61 & 205 & 29 \\
\hline & RH-M2 & 50 & 200 & 450 & 1.125 & 2,5 & 1.734 & 1,9 & 109 & 307 & 29 \\
\hline & RH-L2 & 50 & 200 & 600 & 1.500 & 2,5 & 2.323 & 1,9 & 126 & 410 & 29 \\
\hline & RH-M3 & 50 & 300 & 450 & 1.125 & 2,5 & 2.694 & 2,0 & 154 & 473 & 29 \\
\hline & RH-L4 & 50 & 400 & 600 & 1.500 & 2,5 & 4.645 & 1,9 & 262 & 820 & 29 \\
\hline
\end{tabular}


Table A2. Database of tests on reinforced concrete beams without shear reinforcement (cont.).

\begin{tabular}{|c|c|c|c|c|c|c|c|c|c|c|c|}
\hline Author & Beam & RCA (\%) & $b_{\mathrm{w}}(\mathrm{mm})$ & $d(\mathrm{~mm})$ & $a(\mathrm{~mm})$ & $a / d$ & $A_{\mathrm{s}}\left(\mathrm{mm}^{2}\right)$ & $\rho_{1}(\%)$ & $V_{\mathrm{u}}(\mathrm{kN})$ & $V_{\text {flex }}(\mathrm{kN})$ & $f_{\text {ck }}(\mathrm{MPa})$ \\
\hline \multirow{12}{*}{ Schubert et al. [16] } & RC-M-1 Q1 & 50 & 500 & 170 & 560 & 3,3 & 1.080 & 1,3 & 118 & 159 & 28 \\
\hline & RC-M-1 Q2 & 50 & 500 & 170 & 560 & 3,3 & 1.080 & 1,3 & 118 & 159 & 27 \\
\hline & RC-M-2 Q1 & 50 & 500 & 170 & 560 & 3,3 & 1.080 & 1,3 & 112 & 159 & 27 \\
\hline & RC-M-2 Q2 & 50 & 500 & 170 & 560 & 3,3 & 1.080 & 1,3 & 102 & 159 & 27 \\
\hline & RC-C-1 & 100 & 500 & 170 & 560 & 3,3 & 1.080 & 1,3 & 116 & 161 & 31 \\
\hline & RC-C-2 Q1 & 100 & 500 & 170 & 560 & 3,3 & 1.080 & 1,3 & 123 & 163 & 34 \\
\hline & RC-C-2 Q2 & 100 & 500 & 170 & 560 & 3,3 & 1.080 & 1,3 & 116 & 163 & 34 \\
\hline & RC-C-3 & 100 & 500 & 170 & 560 & 3,3 & 1.080 & 1,3 & 121 & 161 & 30 \\
\hline & RC-M-3 Q1 & 100 & 500 & 170 & 560 & 3,3 & 1.080 & 1,3 & 101 & 154 & 21 \\
\hline & RC-M-3 Q2 & 100 & 500 & 170 & 560 & 3,3 & 1.080 & 1,3 & 101 & 154 & 21 \\
\hline & RC-M-4 Q1 & 100 & 500 & 170 & 560 & 3,3 & 1.080 & 1,3 & 100 & 155 & 22 \\
\hline & RC-M-4 Q2 & 100 & 500 & 170 & 560 & 3,3 & 1.080 & 1,3 & 106 & 156 & 23 \\
\hline \multirow{2}{*}{ Cardoso [26] } & VA100 & 100 & 180 & 250 & 620 & 2,5 & 491 & 1,1 & 48 & 96 & 23 \\
\hline & VB100 & 100 & 180 & 257 & 620 & 2,4 & 942 & 2,0 & 57 & 168 & 23 \\
\hline \multirow{6}{*}{$\begin{array}{l}\text { Arezoumandi et al. } \\
\qquad 4] .\end{array}$} & RAC-NS-4.1 & 100 & 300 & 400 & 1.200 & 3,0 & 1.810 & 1,2 & 115 & 222 & 26 \\
\hline & RAC-NS-4.2 & 100 & 300 & 400 & 1.200 & 3,0 & 1.810 & 1,2 & 113 & 226 & 30 \\
\hline & RAC-NS-6.1 & 100 & 300 & 400 & 1.200 & 3,0 & 1.810 & 2,0 & 143 & 222 & 26 \\
\hline & RAC-NS-6.2 & 100 & 300 & 400 & 1.200 & 3,0 & 1.810 & 2,0 & 124 & 226 & 30 \\
\hline & RAC-NS-8.1 & 100 & 300 & 400 & 1.200 & 3,0 & 1.810 & 2,7 & 131 & 222 & 26 \\
\hline & RAC-NS-8.2 & 100 & 300 & 400 & 1.200 & 3,0 & 1.810 & 2,7 & 140 & 226 & 30 \\
\hline \multirow{5}{*}{ Kim et al. [30] } & RF-S2 & 100 & 200 & 300 & 750 & 2,5 & 1.161 & 1,9 & 73 & 208 & 31 \\
\hline & RF-M2 & 100 & 200 & 450 & 1.125 & 2,5 & 1.734 & 1,9 & 96 & 311 & 31 \\
\hline & RF-L2 & 100 & 200 & 600 & 1.500 & 2,5 & 2.323 & 1,9 & 125 & 416 & 31 \\
\hline & RF-M3 & 100 & 300 & 450 & 1.125 & 2,5 & 2.694 & 2,0 & 160 & 479 & 31 \\
\hline & RF-L4 & 100 & 400 & 600 & 1.500 & 2,5 & 4.645 & 1,9 & 257 & 831 & 31 \\
\hline \multirow{14}{*}{ Sadati et al. [31] } & RAC100-1 & 100 & 170 & 270 & 594 & 2,2 & 505 & 1,1 & 60 & 116 & 36 \\
\hline & RAC100-2 & 100 & 170 & 270 & 810 & 3,0 & 505 & 1,1 & 43 & 83 & 27 \\
\hline & RAC100-3 & 100 & 305 & 400 & 1.240 & 3,1 & 3.306 & 2,7 & 115 & 433 & 26 \\
\hline & RAC100-4 & 100 & 305 & 400 & 1.240 & 3,1 & 2.477 & 2,0 & 113 & 364 & 30 \\
\hline & RAC100-5 & 100 & 305 & 375 & 1.219 & 3,3 & 1.453 & 1,3 & 143 & 216 & 26 \\
\hline & RAC100-6 & 100 & 305 & 375 & 1.219 & 3,3 & 2.322 & 2,0 & 131 & 316 & 26 \\
\hline & RAC100-7 & 100 & 305 & 375 & 1.219 & 3,3 & 3.100 & 2,7 & 124 & 404 & 30 \\
\hline & RAC100-8 & 100 & 305 & 375 & 1.219 & 3,3 & 3.100 & 2,7 & 140 & 404 & 30 \\
\hline & RAC100-9 & 100 & 200 & 303 & 1.000 & 3,3 & 1.757 & 2,9 & 84 & 231 & 36 \\
\hline & RAC100-10 & 100 & 150 & 200 & 760 & 3,8 & 390 & 1,3 & 36 & 51 & 35 \\
\hline & RAC100-11 & 100 & 150 & 200 & 760 & 3,8 & 390 & 1,3 & 38 & 51 & 35 \\
\hline & RAC100-12 & 100 & 150 & 200 & 760 & 3,8 & 390 & 1,3 & 40 & 51 & 35 \\
\hline & RAC100-13 & 100 & 150 & 200 & 760 & 3,8 & 609 & 2,0 & 36 & 75 & 35 \\
\hline & RAC100-14 & 100 & 170 & 270 & 1.080 & 4,0 & 505 & 1,1 & 32 & 62 & 28 \\
\hline \multirow{2}{*}{ Katkhuda [29] } & R100-3 & 100 & 200 & 267 & 800 & 3,0 & 1.018 & 1,9 & 46 & 125 & 19 \\
\hline & T100-3 & 100 & 200 & 267 & 800 & 3,0 & 1.018 & 1,9 & 56 & 128 & 23 \\
\hline \multirow{4}{*}{$\begin{array}{l}\text { Knaackand Kurama } \\
\qquad[28]\end{array}$} & S100-1a & 100 & 150 & 200 & 760 & 3,8 & 390 & 1,3 & 36 & 53 & 35 \\
\hline & S100-1b & 100 & 150 & 200 & 760 & 3,8 & 390 & 1,3 & 38 & 53 & 35 \\
\hline & S100-2a & 100 & 150 & 200 & 760 & 3,8 & 390 & 1,3 & 40 & 53 & 35 \\
\hline & S100-2b & 100 & 150 & 200 & 760 & 3,8 & 390 & 1,3 & 36 & 53 & 35 \\
\hline $\begin{array}{c}\text { Ignjatovic (2013) } \\
\text { [32] }\end{array}$ & RAC1000-1b & 100 & 200 & 235 & 1.000 & 4,3 & 1.922 & 4,1 & 69 & 163 & 31 \\
\hline \multirow{4}{*}{ Choi et al. [19] } & RARAC100-L2.5 & 100 & 200 & 360 & 900 & 2,5 & 382 & 0,5 & 60 & 75 & 19 \\
\hline & RARAC100-M2.5 & 100 & 200 & 360 & 900 & 2,5 & 598 & 0,8 & 70 & 105 & 19 \\
\hline & RARAC100-H2.5 & 100 & 200 & 360 & 900 & 2,5 & 1.159 & 1,6 & 85 & 175 & 19 \\
\hline & RARAC100-H3.5 & 100 & 200 & 360 & 1.170 & 3,3 & 1.159 & 1,6 & 58 & 135 & 19 \\
\hline
\end{tabular}

